\title{
Development of a CAPS Marker and a LAMP Assay for Rapid Detection of Xylella fastidiosa Subsp. multiplex and Differentiation from $X$. fastidiosa Subsp. fastidiosa on Blueberry
}

\author{
Sumyya Waliullah ${ }^{1}$ D , Dario Di Genova ${ }^{2,3}$, Jonathan E. Oliver ${ }^{1}$ and Md Emran Ali ${ }^{1, *(D)}$ \\ 1 Department of Plant Pathology, University of Georgia, Tifton, GA 31793, USA; \\ Sumyya.Waliullah@uga.edu (S.W.); jonathanoliver@uga.edu (J.E.O.) \\ 2 Department of Crop and Soil Sciences, University of Georgia, Tifton, GA 31793, USA; \\ dario.digenova.libero@gmail.com \\ 3 Department of Agronomy, Food, Natural Resources, Animals and Environment, University of Padova, \\ 35020 Legnaro, Italy \\ * Correspondence: emran.ali@uga.edu
}

check for updates

Citation: Waliullah, S.; Di Genova,

D.; Oliver, J.E.; Ali, M.E.

Development of a CAPS Marker and a LAMP Assay for Rapid Detection of Xylella fastidiosa Subsp. multiplex and Differentiation from $X$. fastidiosa Subsp. fastidiosa on Blueberry. Int. J. Mol. Sci. 2022, 23, 1937. https:// doi.org/10.3390/ijms23041937

Academic Editor: Lars Matthias Voll

Received: 16 December 2021

Accepted: 7 February 2022

Published: 9 February 2022

Publisher's Note: MDPI stays neutral with regard to jurisdictional claims in published maps and institutional affiliations.

Copyright: (C) 2022 by the authors. Licensee MDPI, Basel, Switzerland. This article is an open access article distributed under the terms and conditions of the Creative Commons Attribution (CC BY) license (https:// creativecommons.org/licenses/by/ $4.0 /)$.

\begin{abstract}
Bacterial leaf scorch (BLS), caused by Xylella fastidiosa (Xf), is a prevalent disease of blueberries in the southeastern United States. Initially, this disease was reported to be caused by X. fastidiosa subsp. multiplex (Xfm). However, a recent survey revealed the presence of another subspecies, $X$. fastidiosa subsp. fastidiosa (Xff), within naturally infected blueberry plantings in Georgia. Since knowledge regarding the origins of isolates causing Xf outbreaks can impact management recommendations, a routine method for identifying the pathogen at the subspecies level can be beneficial. Several detection strategies are available to identify $X f$ infection at the subspecies level. However, none of these have been developed for the routine and rapid differentiation of the blueberry-infecting Xf subspecies. Here, we developed two separate straightforward and rapid detection techniques, a cleaved amplified polymorphic sequence (CAPS) marker, and a loop-mediated isothermal amplification (LAMP) assay, targeting the RNA polymerase sigma-70 factor $(r p o D)$ gene sequence of $X f m$ to discriminate between the two Xf subspecies infecting blueberry. With the CAPS marker, specific detection of Xfm isolates was possible from pure cultures, inoculated greenhouse-grown plant samples, and field infected blueberry samples by restriction digestion of the rpoD gene PCR product (amplified with primers RST31 and RST33) using the BtsI enzyme. The LAMP assay allowed for specific real-time amplification of a 204-bp portion of the Xfm rpoD gene from both pure bacterial cultures and infected plant material using the Genie ${ }^{\circledR}$ III system, a result further affirmed by gel electrophoresis and SYBR ${ }^{\mathrm{TM}}$ Green I DNA staining for visual observation. These detection strategies have the potential to greatly aid existing diagnostic methods for determining the distribution and prevalence of these Xf subspecies causing bacterial leaf scorch (BLS) in blueberries in the southeastern United States.
\end{abstract}

Keywords: bacterial leaf scorch (BLS); blueberry; subspecies detection; CAPS marker; LAMP

\section{Introduction}

Xylella fastidiosa $(\mathrm{Xf})$ is a Gram-negative, slow growing, and fastidious bacterium in the family Xanthmonadaceae. It is a widely distributed plant pathogen which can colonize the xylem of many different plant species, causing a variety of diseases. At least 595 plant species from 275 genera and 85 families have been reported to be infected with $X f$ or Xylella taiwanensis [1,2]. However, $X f$ does not appear to cause disease in most of these plant species, and symptoms and diseases caused by $X f$ vary among hosts. The most notorious diseases caused by this pathogen include Pierce's disease (PD), citrus variegated chlorosis (CVC), phony peach disease (PPD), and several leaf scorch diseases 
such as almond leaf scorch (ALS), oleander leaf scorch (OLS), coffee leaf scorch (CLS), mulberry leaf scorch (MLS), olive quick decline syndrome (OQDS), and plum leaf scald (PLS) [3-6]. Another disorder caused by Xf, named BLS, was first observed in 2004 affecting southern highbush (SHB) blueberry cultivars in the state of Georgia [7] (U.S.A.) and later in Florida [8]. Disease symptoms of BLS include initial marginal chlorosis of older leaves followed by severe leaf scorch, partial defoliation, severely reduced vegetative growth with reduced numbers of flower buds, dieback, and ultimately death of the plant [7-9]. Diseases caused by Xf are spread from plant to plant via insect transmission [10], and also by vegetative propagation [11]. Among the insect vectors of $X f$, glassy-winged sharpshooter (Homalodisca vitripennis) is the most common vector found in blueberry plantings in the southeastern United States [12].

$\mathrm{Xf}$ is a genetically diverse species that appears to have originated in the Americas [11], and several distinct subspecies have been described, including fastidiosa, multiplex, pauca, sandyi, morus, and tashke [13]. This subspecies classification was proposed based on genetic characterization of specific k-mers within the 16S rRNA gene, the 16S-23S intergenic spacer region, and multilocus sequence typing analyses (MLSTs) [10,13-15]. Among these subspecies, three (fastidiosa, multiplex, and pauca) are well-characterized as the causes of damaging diseases on numerous hosts worldwide, while knowledge regarding the other subspecies (sandyi, morus, and tashke) appears to be more limited [13]. Furthermore, it is hard to rule out the existence of additional uncharacterized subspecies, as most of the studies on genetic diversity were carried out on cultivated crops, as well as wild grasses, sedges, and forest trees [1].

Though the actual mechanism of host plant-pathogen specificity is yet to be determined, $X f$ subspecies show host specificity, and it is presumed that genetic variation among subspecies is a determinant of host range. PD of grapevines is caused by $X f$ subsp. fastidiosa (Xff) while Xf subsp. multiplex (Xfm) causes leaf scorch diseases on multiple plant hosts, including blueberry, almond, oak, and peach in North America [11,16,17]. Additionally, $X f$ subsp. pauca (Xfp), causes CVC and CLS in Brazil and OQDS in Italy, while Xf subsp. sandyi $(X f s)$ causes OLS $[11,18]$. Cross-inoculation of $X f$ isolates from one host to another have often failed to infect the other plant [19]. Failure of Xfm isolates from peaches to infect grapevine and Xff isolates from grapevine to infect peaches provide some examples [19]. Similarly, Xfs isolates from oleander do not infect grapes and Xff isolates from grapes do not infect oleander [19]. However, reports suggest that the host range of $X f$ isolates can be extended upon disruption of the cell-to-cell signaling-based gene regulation system [20]. A recent study by Saponari et al. [3] showed that Xfp strain De Donno could infect olive, oleander, and myrtle-leaf milkwort in greenhouse conditions. Infection of the same plant host with multiple $X f$ subspecies has also been reported. For example, ALS is reported to be caused by isolates from both Xfm and Xff subspecies [4,19].

Initially, the $X f$ isolates obtained from BLS diseased blueberry plants were entirely identified as $X f m[14,15,21,22]$. However, in addition to $X f m$, recent studies showed that southern highbush blueberry plants can also be infected with Xff isolates under greenhouse and field conditions [16,17]. Upon genetic characterization of the $r p o D$ gene and utilizing MLST approaches, Di Genova et al. [17] reported that isolates from both subspecies Xfm and Xff could be found naturally infecting blueberry plantings in southeastern Georgia. Since isolates from these two different subspecies have variable virulence and pathogenicity $[16,23]$, appropriate management recommendations may vary depending on the primary subspecies involved. As such, it is important to understand the distribution and prevalence of these subspecies in blueberry and have precise and prompt methods to differentiate the isolates of Xfm and Xff affecting this host.

There are several PCR-based detection techniques available to characterize and differentiate between $X f$ subspecies and strains. PCR-RFLP and RAPD are widely used molecular techniques to identify strains and pathotypes of $X f$ [24-26]. In previous studies, using a series of specific PCR primers targeting multiple genes and subsequent sequencing of PCR or PCR-RAPD products, several host-specific Xf strains including CVC, OLS, 
MLS, and OQDS strains were detected [23,27-30]. Nested-PCR (N-PCR), a PCR derivative with increased sensitivity, was applied to identify several strains of $X f$ from American elm, grapevine tissues, citrus plants and sharpshooter leafhoppers [31-33]. Exploiting single-nucleotide polymorphisms (SNPs) of $16 \mathrm{~S}$ rDNA, gyrase B subunit (gyrB) and HL hypothetical protein genes, a genetic diversity and phylogenetic analysis based on PCR and subsequent sequencing was carried out on $X f$ from Apulian olive trees revealing the subspecies identity as pauca [34]. qRT-PCR (SYBR green or TaqMan) is also a common molecular technique employed to discriminate and identify Xf strains causing PD, ALS, OLS, and CVC [35-38]. A digital droplet PCR assay was utilized to detect $X f$ by adapting a qPCR assay from Harper et al. [39], which targeted the 16S rRNA processing protein gene (rim) of the pathogen [40]. In addition, another novel technique, loop-mediated isothermal amplification (LAMP), has also been used to detect $X f$, as it is a good alternative to PCR that is straightforward and rapid with higher specificity and sensitivity [39,41,42]. However, none of these assays were specifically designed to identify and discriminate between the $\mathrm{Xff}$ and $\mathrm{Xfm}$ isolates infecting blueberry.

Therefore, we developed two molecular techniques (i.e., a cleaved amplified polymorphic sequence (CAPS) marker and a LAMP assay targeting the RNA polymerase sigma-70 factor $(r p o D)$ gene of Xfm) to identify and differentiate between Xff and Xfm isolates from blueberries. The aim of this study was to develop and validate simple methods to distinguish between Xff and Xfm isolates efficiently and rapidly. Unlike other methods for subspecies differentiation, the CAPS marker technique does not require the use of multiple PCR primers or subsequent sequencing $[43,44]$, and LAMP is a unique approach widely used for plant pathogen diagnosis for its simplicity, specificity, and sensitivity $[42,45,46]$. In this study, we were able to identify and differentiate between Xff and Xfm isolates from blueberry using these two separate assays. These assays have the potential to enhance existing procedures for detecting the subspecies of the pathogen, greatly aiding investigations of $X f$ spread and isolate diversity which will help shape management recommendations for BLS in blueberry production in the southeastern United States.

\section{Results}

\subsection{Detection and Differentiation of Xfm from Xff Using CAPS Marker}

Use of the BtsI restriction enzyme and a unique restriction site in Xfm (Figure 1A, Supplementary Figure S1) was evaluated for distinguishing between Xfm and Xff isolates from blueberry. The enzyme was used to cleave RST PCR products (abbreviated name of PCR product amplified using primer set RST31/RST33, Supplementary Table S1) from pure bacterial cultures and greenhouse-grown blueberry plants inoculated with Xfm (AlmaReb3 and AlmaStar1) or Xff (AlmaReb1 and AlmaReb2) isolates. Regardless of the origin of the PCR products, restriction digested PCR fragments were only detected from Xfm samples, while polymorphisms were not detected with BtsI digests from Xff samples (Figure 1 and Section 2.2). Presence of the cleaved 609-bp and 124-bp bands from the 733bp RST PCR products indicated the presence of Xfm isolates in both experiments (Figure 1 and Section 2.2).

\subsection{Detection and Differentiation of Infected Field Samples Using CAPS Marker}

A total of $26 \mathrm{Xf}$ positive SHB field samples (Table 1) were screened by CAPS marker for subspecies detection and differentiation. Upon digestion of RST PCR products with BtsI, 21 cleaved PCR products were observed following gel electrophoresis (Figure 3). The separated 609-bp and 124-bp bands indicate infection with Xfm, whereas the other 5 undigested PCR products indicate infection with Xff. The subspecies identity of the infected field samples was further affirmed by direct sequencing of the PCR product (Table 1). 


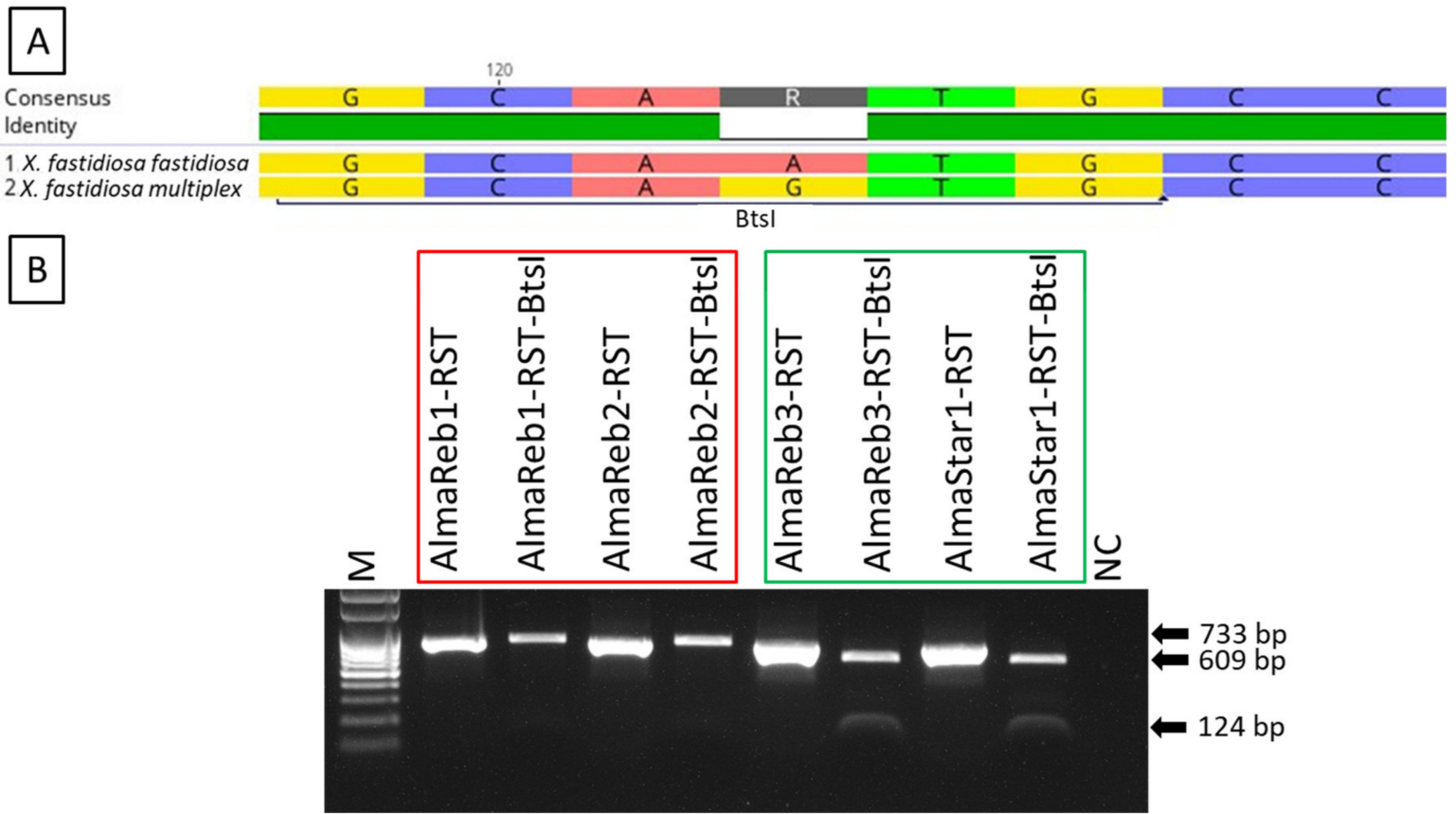

Figure 1. BtsI restriction digestion of X. fastidiosa RST PCR products from pure bacterial cultures of blueberry isolates from both subspecies. (A) Partial sequence showing the BtsI restriction site in aligned DNA using consensus sequences from X. fastidiosa subsp. multiplex and X. fastidiosa subsp. fastidiosa (for more information see Supplementary Figure S1). (B) Agarose gel electrophoresis of BtsI restriction digestion fragments of the RST PCR products from DNA extracted from pure cultures of the respective isolates of X. fastidiosa subsp. multiplex and X. fastidiosa subsp. fastidiosa. The red box indicates X. fastidiosa subsp. fastidiosa isolates and the green box indicates X. fastidiosa subsp. multiplex isolates. "-RST" indicates the undigested product, and "-RST-BtsI" indicates the PCR product after use of the BtsI restriction enzyme. M, 100 bp ladder marker; $\mathrm{NC}$, nuclease-free $\mathrm{H}_{2} \mathrm{O}$ used as the negative control. Black arrows indicate the product size in base pairs. Bands of 609-bp and 124-bp can be observed after BtsI digestion of the RST PCR products from pure cultures of X. fastidiosa subsp. multiplex isolates.

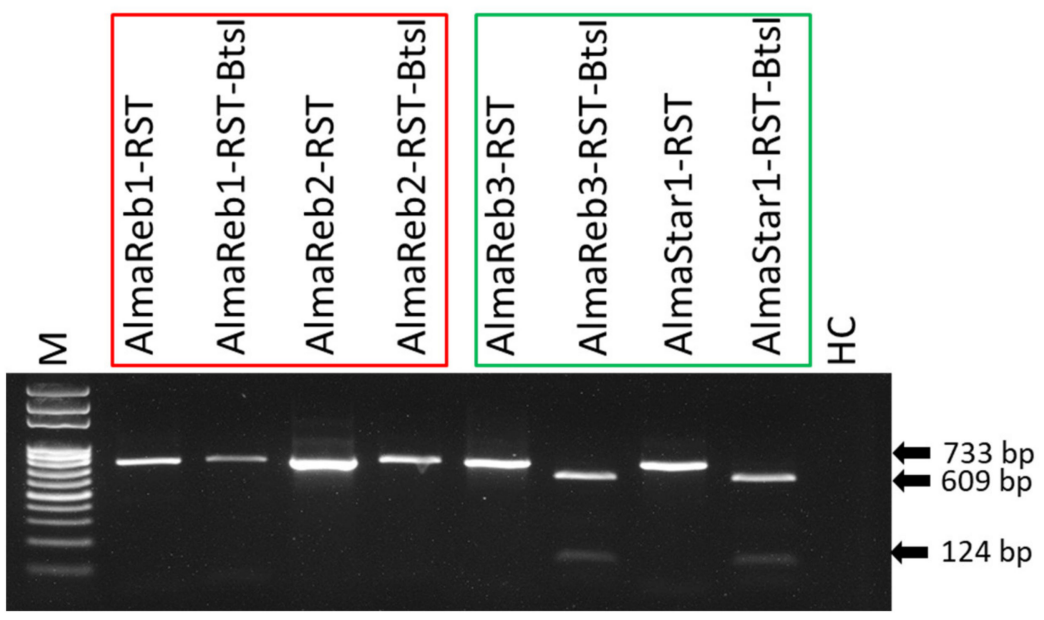

Figure 2. BtsI restriction digestion of X. fastidiosa subsp. multiplex RST PCR products from infected greenhouse-grown blueberry plant samples. Agarose gel electrophoresis of BtsI restriction digestion fragments of the RST PCR products from DNA extracted from greenhouse-grown plants infected with the respective isolates of $X$. fastidiosa subsp. multiplex and X. fastidiosa subsp. fastidiosa. The red box indicates plant samples infected with $X$. fastidiosa subsp. fastidiosa isolates and the green box indicates 
plants samples infected with X. fastidiosa subsp. multiplex isolates. "-RST" indicates the undigested product, and "-RST-BtsI" indicates the PCR product after use of the BtsI restriction enzyme. M, $100 \mathrm{bp}$ ladder marker; HC, healthy SHB plant sample as healthy control. Black arrows indicate the product size in base pairs. Bands of 609-bp and 124-bp can be observed only after BtsI digestion of the RST PCR products from plants infected with X. fastidiosa subsp. multiplex isolates.

Table 1. List of the $X$. fastidiosa infected blueberry field samples used in this study for subspecies detection and differentiation using CAPS marker and LAMP assay. Subspecies identity was further confirmed by direct sequencing of the RST PCR product.

\begin{tabular}{|c|c|c|c|c|c|c|}
\hline Sample no. & $\begin{array}{c}\text { SHB } \\
\text { Cultivar }\end{array}$ & $\begin{array}{c}\text { Year of } \\
\text { Collection }\end{array}$ & Field Site ID & $\begin{array}{c}\text { Geographic } \\
\text { Location in } \\
\text { Georgia }\end{array}$ & $\begin{array}{c}\text { Subsp. } \\
\text { Identity by } \\
\text { CAPS Marker } \\
\text { and LAMP } \\
\text { Assay }\end{array}$ & $\begin{array}{c}\text { Subsp. } \\
\text { Identity by } \\
\text { Direct } \\
\text { Sequencing }\end{array}$ \\
\hline FS1 & Rebel & 2019 & Site 1 & Bacon County & $X f m$ & $X f m$ \\
\hline FS2 & Rebel & 2019 & Site 1 & Bacon County & Xfm & $X f m$ \\
\hline FS3 & Rebel & 2019 & Site 1 & Bacon County & Xfm & $X f m$ \\
\hline FS4 & Rebel & 2019 & Site 1 & Bacon County & Xfm & $X f m$ \\
\hline FS5 & Rebel & 2019 & Site 1 & Bacon County & $X f m$ & $X f m$ \\
\hline FS6 & Rebel & 2019 & Site 2 & Bacon County & Xff & $X f f$ \\
\hline FS7 & Rebel & 2019 & Site 2 & Bacon County & $X f m$ & $X f m$ \\
\hline FS8 & Rebel & 2019 & Site 2 & Bacon County & $X f m$ & $X f m$ \\
\hline FS9 & Rebel & 2019 & Site 2 & Bacon County & $X f m$ & $X f m$ \\
\hline FS10 & Rebel & 2017 & Site 2 & Bacon County & $X f m$ & $X f m$ \\
\hline FS11 & Rebel & 2018 & Site 2 & Bacon County & Xff & Xff \\
\hline FS12 & Rebel & 2018 & Site 1 & Bacon County & $X f m$ & $X f m$ \\
\hline FS13 & Rebel & 2018 & Site 1 & Bacon County & $X f m$ & $X f m$ \\
\hline FS14 & Rebel & 2018 & Site 1 & Bacon County & $X f m$ & $X f m$ \\
\hline FS15 & Rebel & 2017 & Site 2 & Bacon County & Xff & $X f f$ \\
\hline FS16 & Rebel & 2017 & Site 2 & Bacon County & Xff & Xff \\
\hline FS17 & Rebel & 2017 & Site 2 & Bacon County & $X f m$ & $X f m$ \\
\hline FS18 & Star & 2017 & Site 3 & Bacon County & Xfm & $X f m$ \\
\hline FS19 & Meadowlark & 2017 & Site 4 & Pierce County & Xff & $X f f$ \\
\hline FS20 & Sweet Crisp & 2018 & Site 5 & Ware County & $X f m$ & $X f m$ \\
\hline FS21 & Rebel & 2019 & Site 1 & Bacon County & $X f m$ & $X f m$ \\
\hline FS22 & Rebel & 2019 & Site 1 & Bacon County & $X f m$ & $X f m$ \\
\hline FS23 & Rebel & 2019 & Site 1 & Bacon County & $X f m$ & $X f m$ \\
\hline FS24 & Rebel & 2019 & Site 1 & Bacon County & $X f m$ & $X f m$ \\
\hline FS25 & Rebel & 2019 & Site 1 & Bacon County & $X f m$ & $X f m$ \\
\hline FS26 & Rebel & 2019 & Site 1 & Bacon County & $X f m$ & $X f m$ \\
\hline
\end{tabular}

\subsection{LAMP Condition Optimization for Xfm Detection}

The optimal reaction temperature for the Xfm LAMP assay was determined using $0.1 \mathrm{ng} / \mu \mathrm{L}$ DNA extracted from a pure culture of Xfm isolate AlmaReb3. The newly synthesized LAMP primer sets including F3, B3, FIP [F1c-F2], BIP [B1c-B2], LF and LB designed by Primer Explorer version 5 (Figure 4, Supplementary Table S1) using the RNA polymerase sigma-70 factor rpoD locus from Xfm sequence (Figure 1, Supplementary Table S1) were used to optimize the temperature conditions. Based on the previous studies and this study, the optimum $10 \times$ formulation of the LAMP primer mix was determined to be: $0.2 \mu \mathrm{M}$ each of primers F3 and B3, $0.8 \mu \mathrm{M}$ each of primers LF and LB, and $1.6 \mu \mathrm{M}$ each of primers FIP and BIP [45,46]. To rule out the optimum reaction temperature, a gradient LAMP was performed from 66 to $73{ }^{\circ} \mathrm{C}$ using the $10 \times$ formulation of the six LAMP primers with $0.1 \mathrm{ng} / \mu \mathrm{L}$ of diluted $\mathrm{Xfm}$ pure culture DNA. A reaction conducted at $70{ }^{\circ} \mathrm{C}$ had the optimal outcome with the shortest peak time $\left(\mathrm{Ti}_{\mathrm{amp}}\right)$ of $24 \mathrm{~min}$ and $30 \mathrm{sec}$ and a melting curve with a specific peak at $83.6{ }^{\circ} \mathrm{C}$ (Figure 5, Supplementary Table S2). In our previous studies, we observed that a $60 \mathrm{~min}$ reaction time is adequate for LAMP amplification $[45,46]$. Therefore, 
60 min was determined to be the optimal reaction time to complete amplification of Xfm.

Thus, the optimal reaction conditions for the LAMP were determined to be $70{ }^{\circ} \mathrm{C}$ for $60 \mathrm{~min}$.

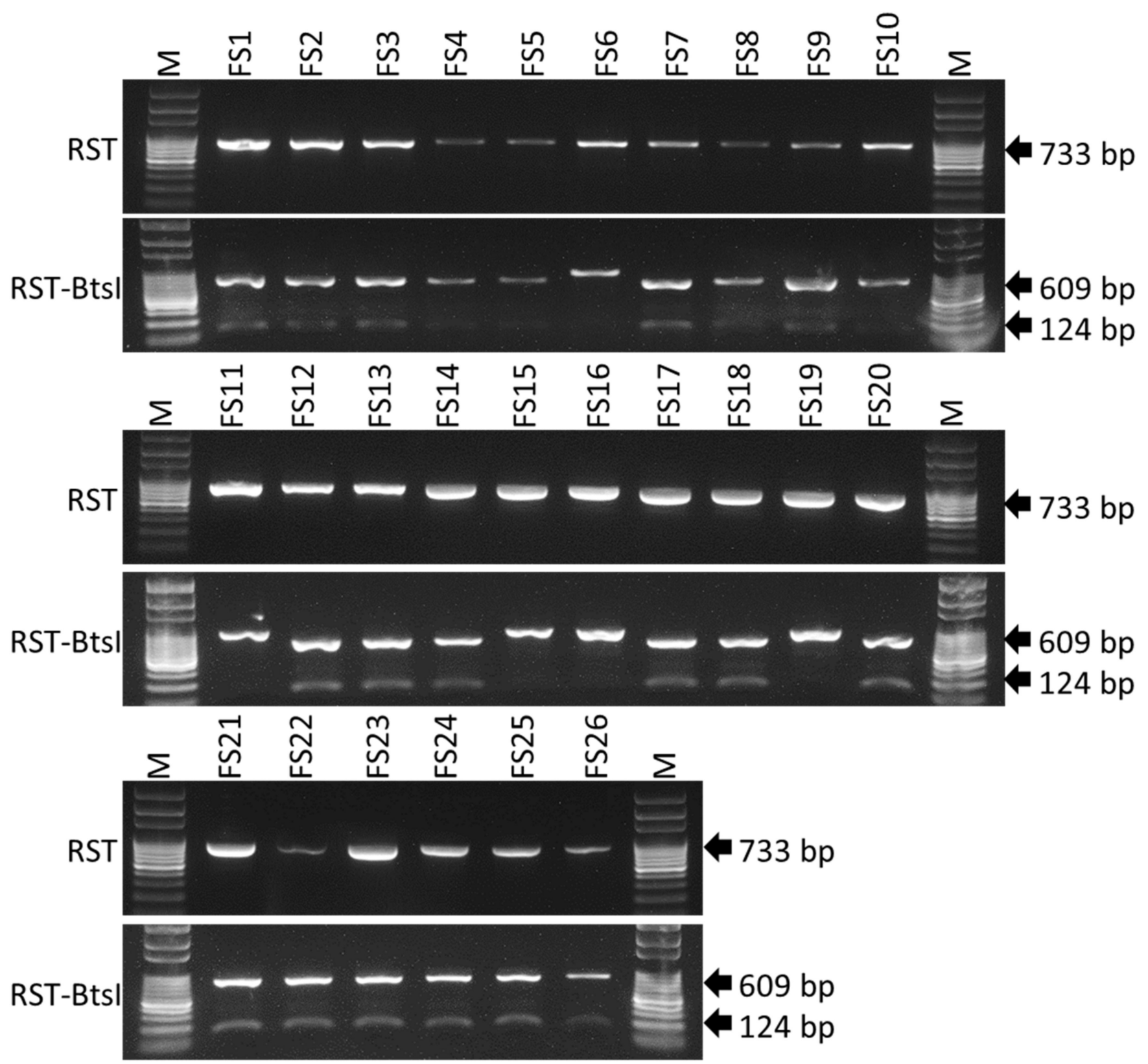

Figure 3. BtsI restriction digestion of X. fastidiosa subsp. multiplex RST PCR products from infected field plant samples. FS1 to FS26: undigested (upper lane on gel photographs) and BtsI-digested (lower lane on gel photographs) RST PCR products of 26 collected field samples positive for X. fastidiosa. $\mathrm{M}=100 \mathrm{bp}$ ladder marker. Black arrows indicate the product size in base pairs. 
F3

FIP (F2)

GAAGTGATTCGATTGCTCCCTTGCTCCCATGTAAACCCATTTCAC

$\mathrm{LF}$

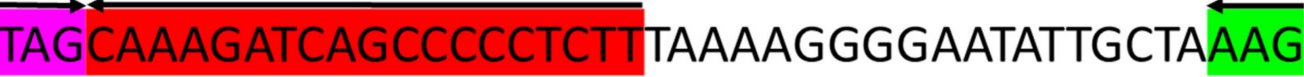

FIP (F1C)

ATCAAAAAGCAACAAACAACGAACAAAGGCAGTGCCGCATCA

$\mathrm{BIP}(\mathrm{B} 1 \mathrm{C})$

ACATCGTACTAGATCACATTTGCTTGCCCTACACGTGATTAAGCA

LB

CGTATGGGAAAGATCCATGAGCAGCTCTGATTCAGTCAATATCA

$\mathrm{BIP}(\mathrm{B} 2)$

B3

Figure 4. Location and partial sequence of loop-mediated isothermal amplification (LAMP) primer sets (F3, B3, FIP [F1c-F2], and BIP [B1c-B2]) targeting X. fastidiosa subsp. multiplex RNA polymerase sigma-70 factor rpoD locus. FIP is a hybrid primer consisting of the F1c sequence and the F2 sequence, $\mathrm{BIP}$ is a hybrid primer consisting of the B1c sequence and the B2 sequence. Arrows indicate the extension direction.

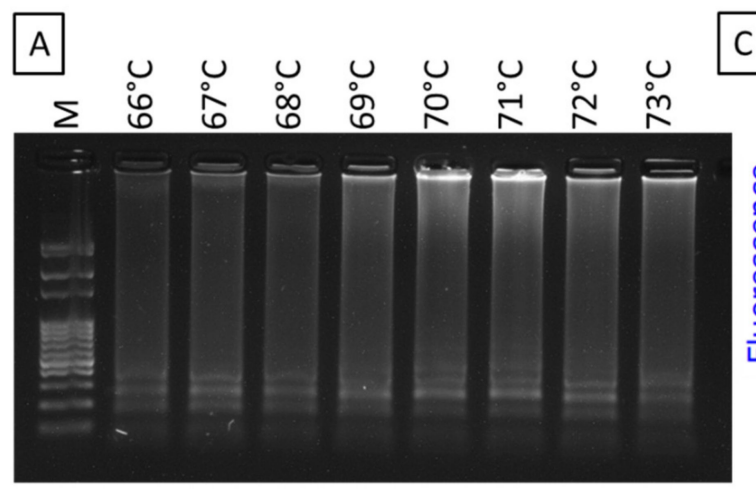

C 200,00

Time (hh:mm:ss)

$B$

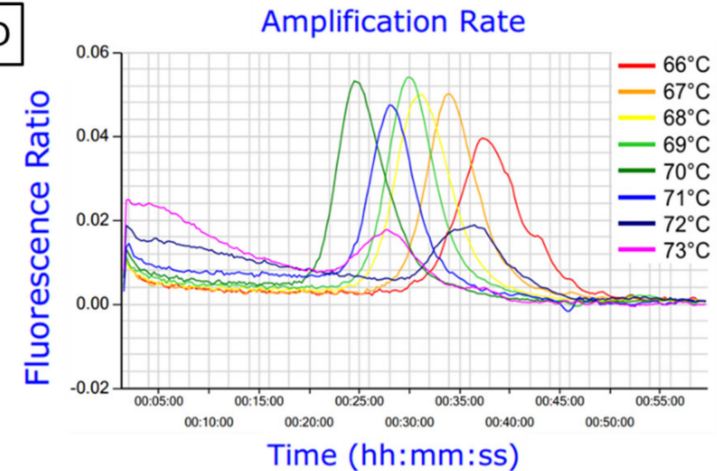

Figure 5. A gradient LAMP for the optimization of reaction temperature for $X$. fastidiosa subsp. multiplex LAMP. Gradient LAMP was set from 66 to $73{ }^{\circ} \mathrm{C}$. Results were analyzed by: (A) agarose gel electrophoresis, (B) SYBR ${ }^{\mathrm{TM}}$ green 1 DNA gel staining agent for visual amplification and (C) real-time amplification by Genie ${ }^{\circledR}$ III. (D) Amplification rate shows the peak value (min:sec) of the amplified curves. Lane $\mathrm{M}=100 \mathrm{bp}$ DNA ladder. The fluorescence green-colored products from the positive LAMP reactions could be visualized after adding SYBR ${ }^{\mathrm{TM}}$ green 1 DNA gel staining agent with the LAMP amplified end product under UV light. 


\subsection{Amplification of Xfm Using LAMP Assay}

To examine the applicability of the LAMP assay for the detection of $X \mathrm{fm}$, the method was evaluated using $0.1 \mathrm{ng} / \mu \mathrm{L}$ of DNA extracted from pure bacterial cultures of $X \mathrm{fm}$ isolates AlmaReb3, AlmaStar1, AlmaStar2, and AlmaStar3. DNA extracted from a second subculture of AlmaStar1, AlmaStar2, and AlmaStar3 was also utilized. Subspecies identities for each pure culture isolate were confirmed by CAPS marker (Figure 6A,B). LAMP primer sets specifically designed targeting the variations among Xfm and Xff rpoD sequences (Supplementary Figure S3) could detect Xfm isolates (Figure 6). All seven cultures from Xfm isolates demonstrated positive amplification of LAMP with gel electrophoresis (Figure 6C), SYBR ${ }^{\mathrm{TM}}$ Green I nucleic acid gel stain (Figure 6D), and Genie ${ }^{\circledR}$ III (OptiGene, Horsham, WS, UK) real-time amplification system (Figure 6E). No amplification was observed in the negative control (Figure 6).

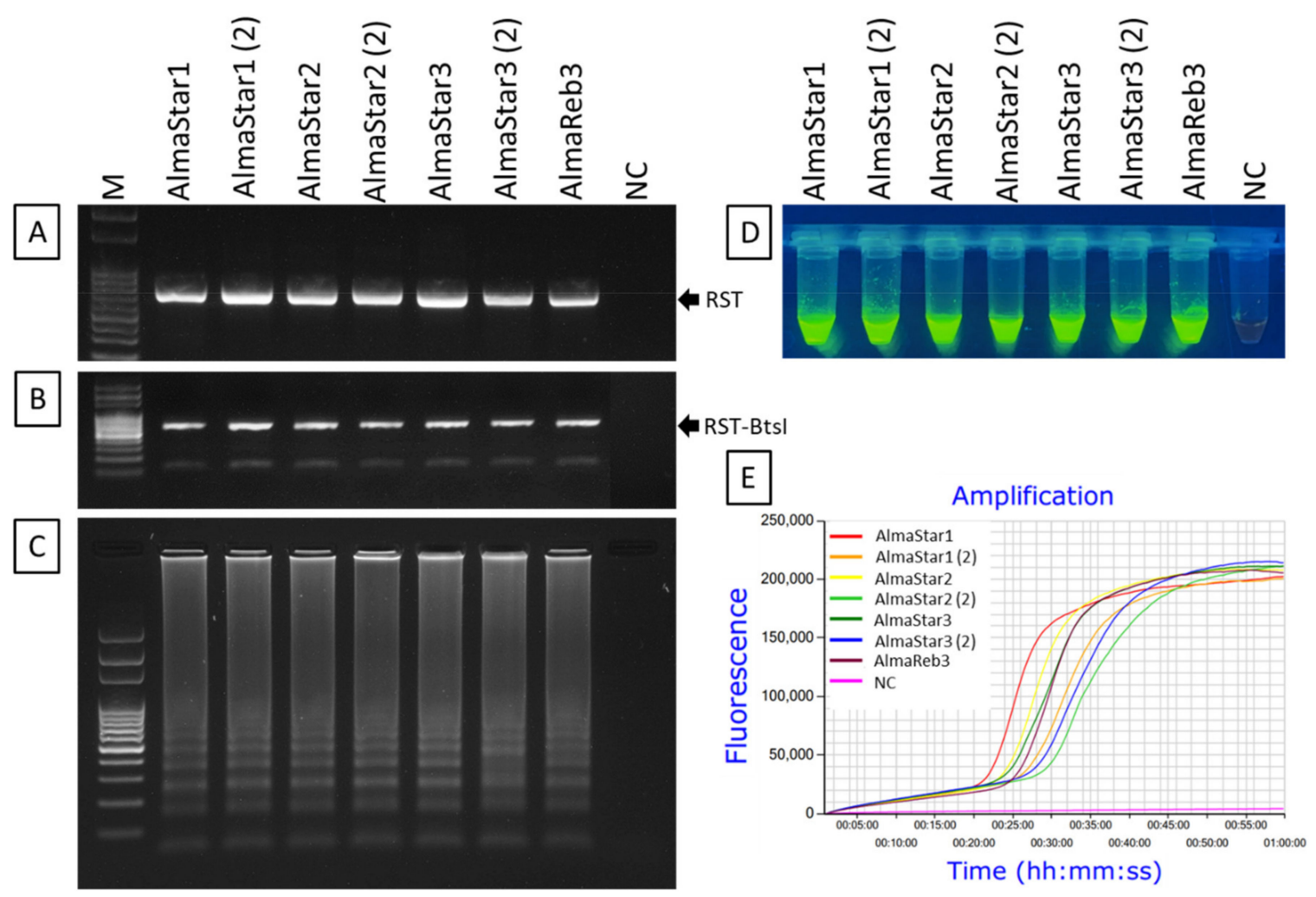

Figure 6. LAMP detection of $X$. fastidiosa subsp. multiplex from DNA derived from pure bacterial cultures. (A,B). Amplified RST PCR products were digested with BtsI restriction enzyme for subspecies confirmation. Successful LAMP amplification of those isolates was visualized using: (C) agarose gel electrophoresis, (D) colorimetric visual inspection by adding SYBR ${ }^{\mathrm{TM}}$ green 1 DNA gel staining agent, and (E) real-time amplification using Genie ${ }^{\circledR}$ III. All isolates depicted belong to X. fastidiosa subsp. multiplex. The (2) following the isolate name indicates that DNA from a second subculture of the same isolate was tested. M, 100 bp DNA ladder; and NC, nuclease-free $\mathrm{H}_{2} \mathrm{O}$ used as the negative control. The fluorescent green-colored products for each isolate, excluding the negative control, could be visualized after adding SYBR ${ }^{\mathrm{TM}}$ green 1 DNA gel staining agent under UV light.

\subsection{Sensitivity of LAMP Detection of Xfm}

Sensitivity of the LAMP primers was assessed using a series of 10-fold dilutions of total DNA (10 to $10^{-7} \mathrm{ng} / \mu \mathrm{L}$ or $10 \mathrm{ng} / \mu \mathrm{L}$ to $0.1 \mathrm{fg} / \mu \mathrm{L}$ ) extracted from Xfm isolate AlmaReb3. The amplification result from Genie ${ }^{\circledR}$ III demonstrated that LAMP amplified products were readily detectable until $1 \mathrm{pg} / \mu \mathrm{L}$ with a true amplification curve, higher amplification rate, and anneal derivative (Figure 7C-E). Genie ${ }^{\circledR}$ III amplified LAMP product was further confirmed by gel electrophoresis and SYBR ${ }^{\mathrm{TM}}$ Green I DNA gel staining agent (Invitrogen, 
Waltham, MA, USA) for visual observation. Ladder-like amplified LAMP product was only visible up to $1 \mathrm{pg} / \mu \mathrm{L}$ of DNA in the gel electrophoresis photograph, whereas lower DNA concentrations showed a smear or no amplified product (Figure 7A). A similar data outcome was observed with adding SYBR ${ }^{\mathrm{TM}}$ green 1 DNA gel staining agent (Invitrogen) under UV light, where bright green fluorescent colored products were visible with higher DNA concentrations and weak or negative reactions turned gradually to orange in color (Figure 7B). Therefore, the sensitivity of the LAMP assay was determined to be $1 \mathrm{pg} / \mu \mathrm{L}$ of DNA (Figure 7, Supplementary Table S3).
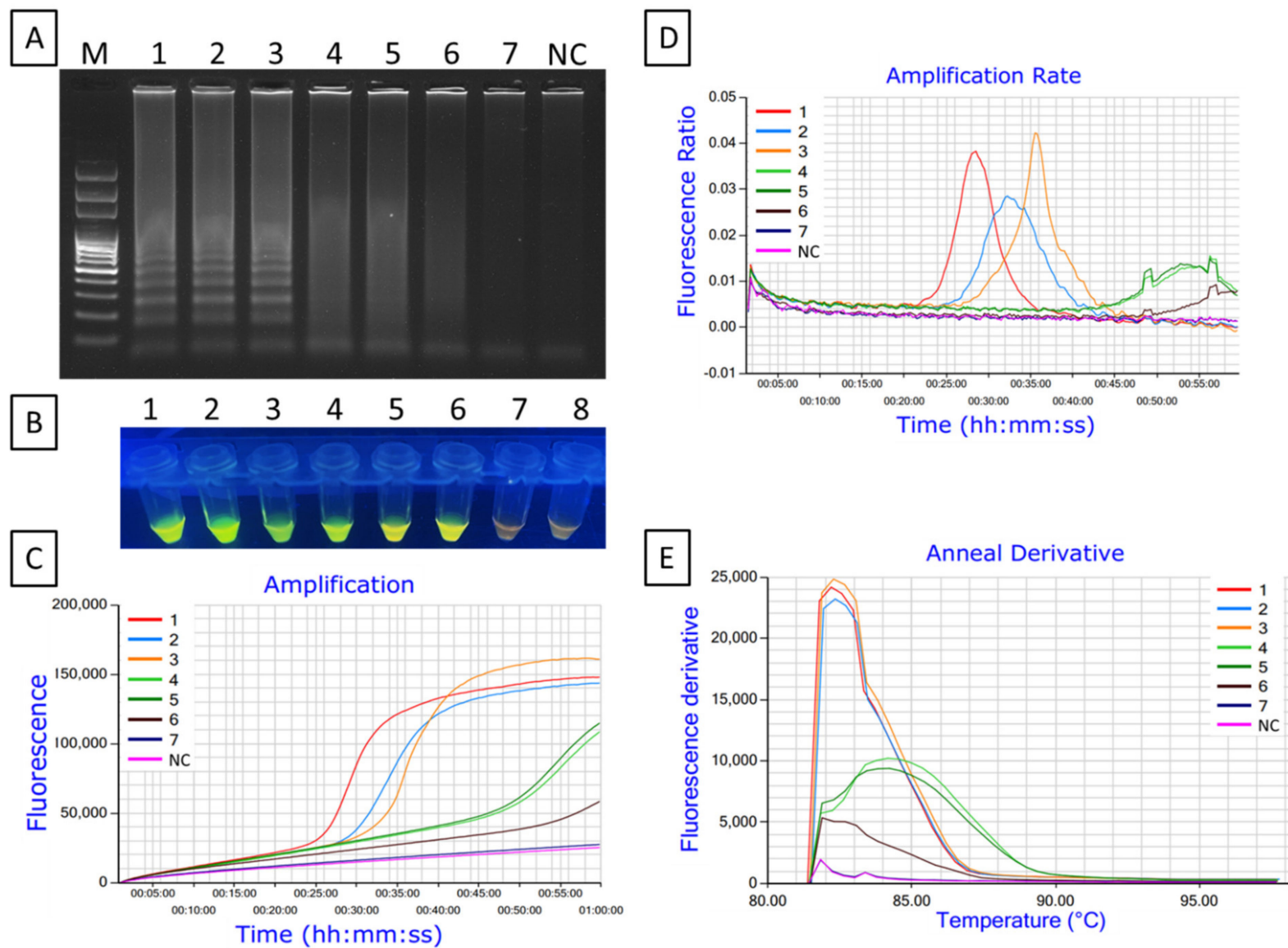

Figure 7. Sensitivity of the LAMP assay for the detection of X. fastidiosa subsp. multiplex using DNA from Xfm isolate AlmaReb3. Amplified LAMP products were analyzed using: (A) agarose gel electrophoresis, (B) visual inspection with $\mathrm{SYBR}^{\mathrm{TM}}$ green 1 DNA gel staining agent, and (C) real-time amplification using Genie ${ }^{\circledR}$ III. (D, E) amplification rate and anneal derivative curves obtained from Genie ${ }^{\circledR}$ III. Here, 1 to $7: 100 \mathrm{pg} / \mu \mathrm{L}$ to $0.0001 \mathrm{pg} / \mu \mathrm{L}$ of Xfm DNA. M, $100 \mathrm{bp}$ DNA ladder; NC, nuclease-free $\mathrm{H}_{2} \mathrm{O}$ used as a negative control. The fluorescent green-colored products could be visualized after adding SYBR ${ }^{\mathrm{TM}}$ green 1 DNA gel staining agent to the end product under UV light while negative reactions remained orange in color.

\subsection{Specificity of LAMP Detection of Xfm}

Specificity of the LAMP primers was assessed using $0.1 \mathrm{ng}$ of DNA from Xfm blueberry isolates AlmaReb3 and AlmaStar1 and Xff blueberry isolates AlmaReb1 and AlmaReb2. For further confirmation, RST PCR products (Figure 8A) were digested with the BtsI restriction enzyme (Figure 8B). An additional specificity test was carried out with 7 isolates ( 3 Xff and 4 Xfm) to further affirm LAMP primers amplification specificity (Supplementary Figure S2). After LAMP amplification, only Xfm isolates showed positive reaction by LAMP, while no amplification by the LAMP assay was observed from Xff isolates or the negative control (Figure $8 \mathrm{C}-\mathrm{E}$ ). Results were confirmed using three different detection strategies including 
agarose gel image analysis (Figure 8C), SYBR ${ }^{\mathrm{TM}}$ green-based UV fluorescence (Figure 8D) and Genie ${ }^{\circledR}$ III amplification curve analysis (Figure $8 \mathrm{E}$ ). All three detection strategies showed a positive reaction only for DNA from Xfm isolates, but not from Xff isolate DNA or the negative control (Figure 8). The results indicated that the LAMP assay could distinguish Xfm isolates from blueberry from Xff isolates from blueberry. An alignment of the LAMP primer binding sites in Xfm versus Xff illustrates how the LAMP assay could specifically distinguish between these two subspecies (Figure 9, Supplementary Figure S3). The nucleotide differences between Xfm and Xff within the targeted $r p o D$ region illustrate how specific detection of Xfm occurs (Figure 9, Supplementary Figure S3).
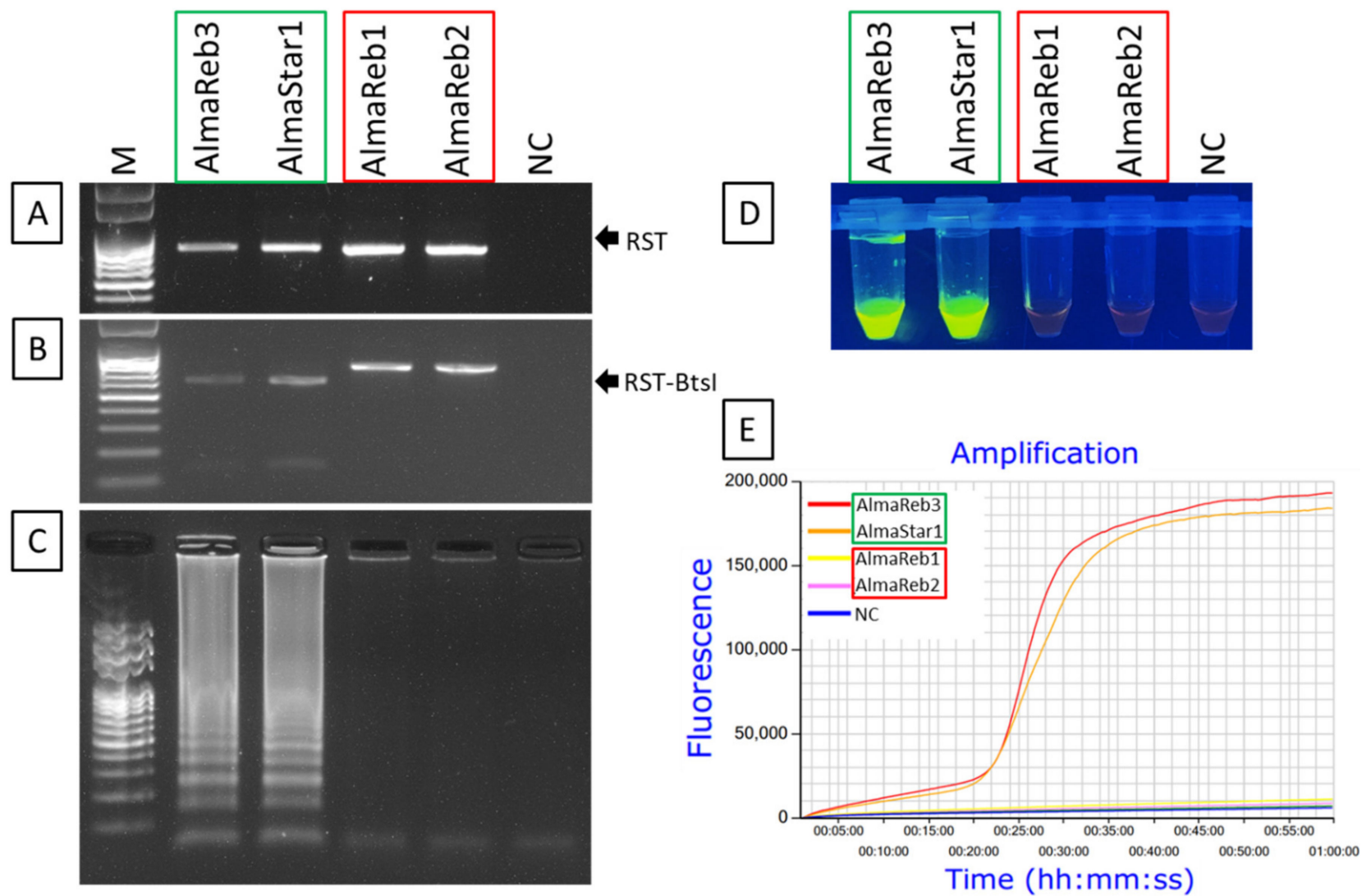

Figure 8. Specificity of the LAMP assay for the detection of X. fastidiosa subsp. multiplex using DNA from pure cultures of blueberry $X$. fastidiosa isolates from both subspecies. The red box indicates X. fastidiosa subsp. fastidiosa isolates and the green box indicates X. fastidiosa subsp. multiplex isolates. (A,B) Amplified RST PCR products were digested with BtsI restriction enzyme for subspecies confirmation. Amplified LAMP products were analyzed using: (C) agarose gel electrophoresis, (D) visual inspection with SYBR ${ }^{\mathrm{TM}}$ green 1 DNA gel staining agent, and (E) real-time amplification using Genie ${ }^{\circledR}$ III. M, 100 bp DNA ladder; NC, nuclease-free $\mathrm{H}_{2} \mathrm{O}$ as a negative control. The fluorescent green-colored products could be visualized after adding SYBR ${ }^{\mathrm{TM}}$ green 1 DNA gel staining agent to the end product under UV light while negative reactions remained orange in color. 


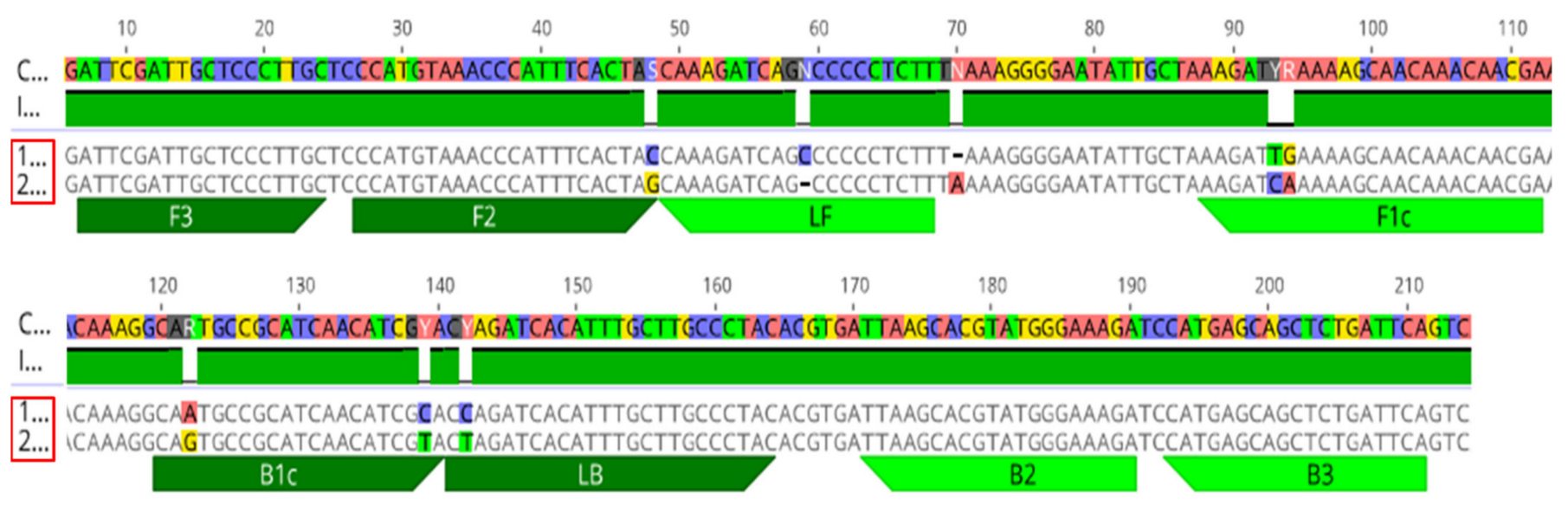

Figure 9. An alignment showing SNPs, insertion and deletion mutations (colored letters) for X. fastidiosa subsp. multiplex LAMP primer binding sites versus $X$. fastidiosa subsp. fastidiosa in rpoD consensus sequences. The red box is showing the numbers, where 1: X. fastidiosa subsp. fastidiosa, 2: X. fastidiosa subsp. multiplex. Here: C, consensus; I, identity. For more information, see Supplementary Figure S3.

\subsection{Detection of Xfm from Greenhouse-Grown and Infected Field Samples Using Probe- Based LAMP}

The specificity of the LAMP primers was also tested with the same greenhouse and infected field leaf samples that were assessed here with the CAPS marker (Section 2.2 and Figure 3). However, preliminary results using the LAMP assay on infected blueberry leaf samples were not consistent. To enable LAMP amplification of infected host samples, a Florescence resonance energy transfer (FRET)-based assimilating probe [47] was developed that enabled the detection of Xfm directly from infected blueberry samples using LAMP (Supplementary Figure S5, Supplementary Table S1, Figures 10 and 11). The reaction conditions for the probe-based LAMP were optimized for reaction temperature and probe/primer mixture volume using $0.1 \mathrm{ng} / \mu \mathrm{L}$ DNA extracted from Xfm isolate AlmaReb3. The optimized temperature for the probe-based LAMP was determined with a gradient LAMP, where the fastest LAMP amplification was obtained at $70{ }^{\circ} \mathrm{C}$ (Supplementary Figure S6A,B; Supplementary Table S4). The primer/probe mixture volume of $2.5 \mu \mathrm{L}$ with a concentration of $0.2 \mu \mathrm{M}$ of F3 and B3, 1.6 $\mu \mathrm{M}$ of FIP and BIP, $0.1 \mu \mathrm{M}$ of the quench (Q) strand and $0.2 \mu \mathrm{M}$ of the FAM-tagged LB assimilating probe with $0.8 \mu \mathrm{M}$ of LF primer was considered as an optimized reaction condition, where no false amplification with negative control occurred and efficient amplification with the positive control manifested by the observation of a true sigmoid amplification curve (Supplementary Figure S6C,D). The sensitivity test with 10 -fold serially diluted DNA $\left(10\right.$ to $10^{-7} \mathrm{ng} / \mu \mathrm{L}$ or $10 \mathrm{ng} / \mu \mathrm{L}$ to $\left.0.1 \mathrm{fg} / \mu \mathrm{L}\right)$ from AlmaReb3 revealed that the detection limit of the probe-based LAMP was at $0.1 \mathrm{pg} / \mu \mathrm{L}$ (Supplementary Figure S7, Supplementary Table S5). However, a true sigmoid amplification curve was only observed down to $10 \mathrm{pg} / \mu \mathrm{L}$ with a brighter ladder-like gel electrophoresis band (Supplementary Figure S7). The optimized FAM-tagged probe/primer set was then primarily assessed with culture grown Xfm isolates as well as with greenhouse-grown infected plant samples. The initial experiments demonstrated that the probe-based LAMP assay was successfully able to selectively amplify Xfm from laboratory-grown isolates and infected plant samples without any cross-reactions (Figure 10). The $26 \mathrm{Xf}$ positive SHB field samples (Table 1) that were screened by CAPS marker for subspecies detection and differentiation were also screened with the modified probe-based LAMP assay. Among those infected field samples, 21 LAMP amplified samples were Xfm infected SHB leaf samples, which matched perfectly with the results from CAPS marker and direct sequencing of the RST PCR product (Figure 11, Table 1). 

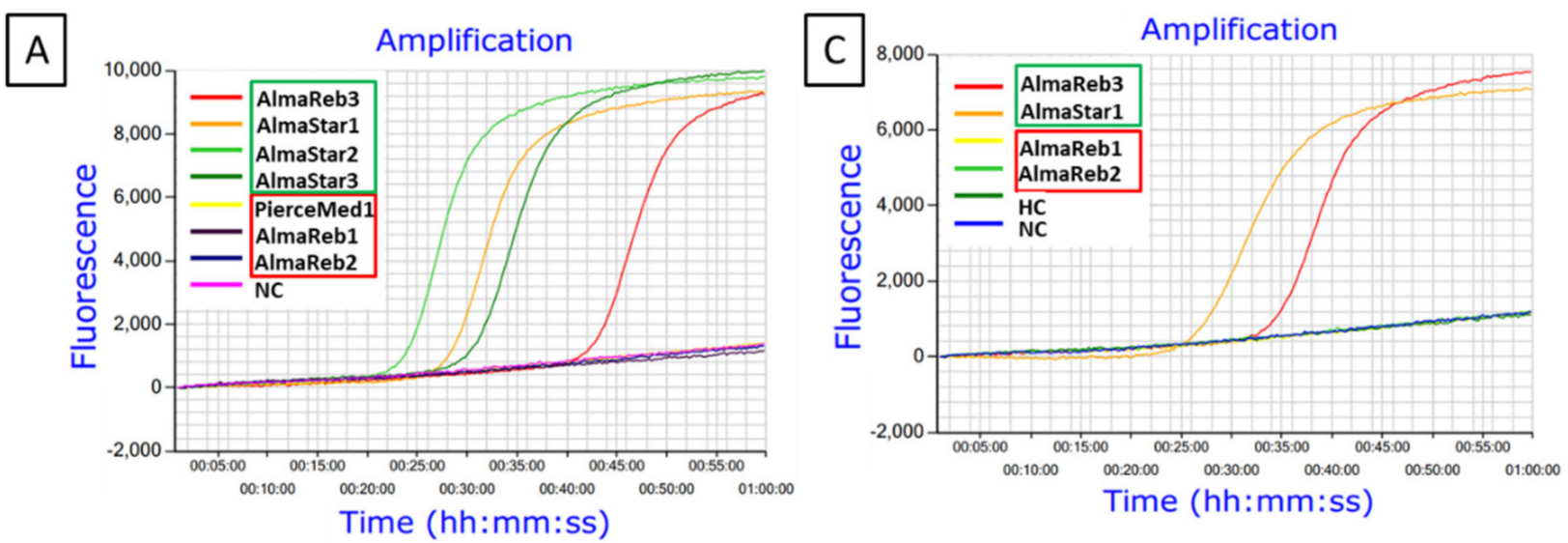

$\mathrm{B}$
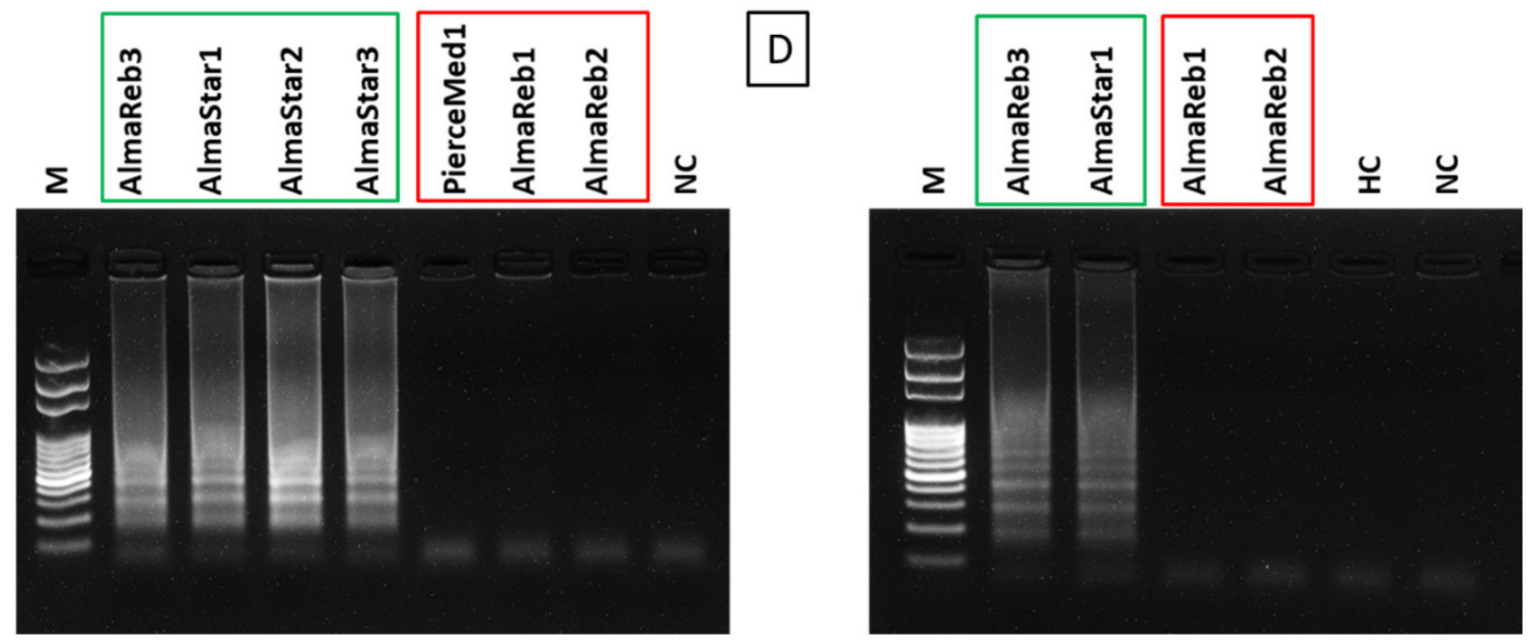

Figure 10. Detection of $X$. fastidiosa subsp. multiplex from known bacterial cultures $(\mathbf{A}, \mathbf{B})$ and infected greenhouse-grown samples (C,D) by probe-based LAMP. Successful LAMP amplification of Xfm isolates or infected plant tissues were visualized using real-time amplification with Genie ${ }^{\circledR}$ III $(\mathbf{A}, \mathbf{C})$ and with agarose gel image (B,D). The red box indicates $X$. fastidiosa subsp. fastidiosa $(X f f)$ isolates or infected greenhouse-grown samples and the green box indicates X. fastidiosa subsp. multiplex (Xfm) isolates or infected greenhouse-grown samples. Here: M, 100 bp DNA ladder; $\mathrm{NC}$, nuclease free $\mathrm{H}_{2} \mathrm{O}$ used as the negative control. 

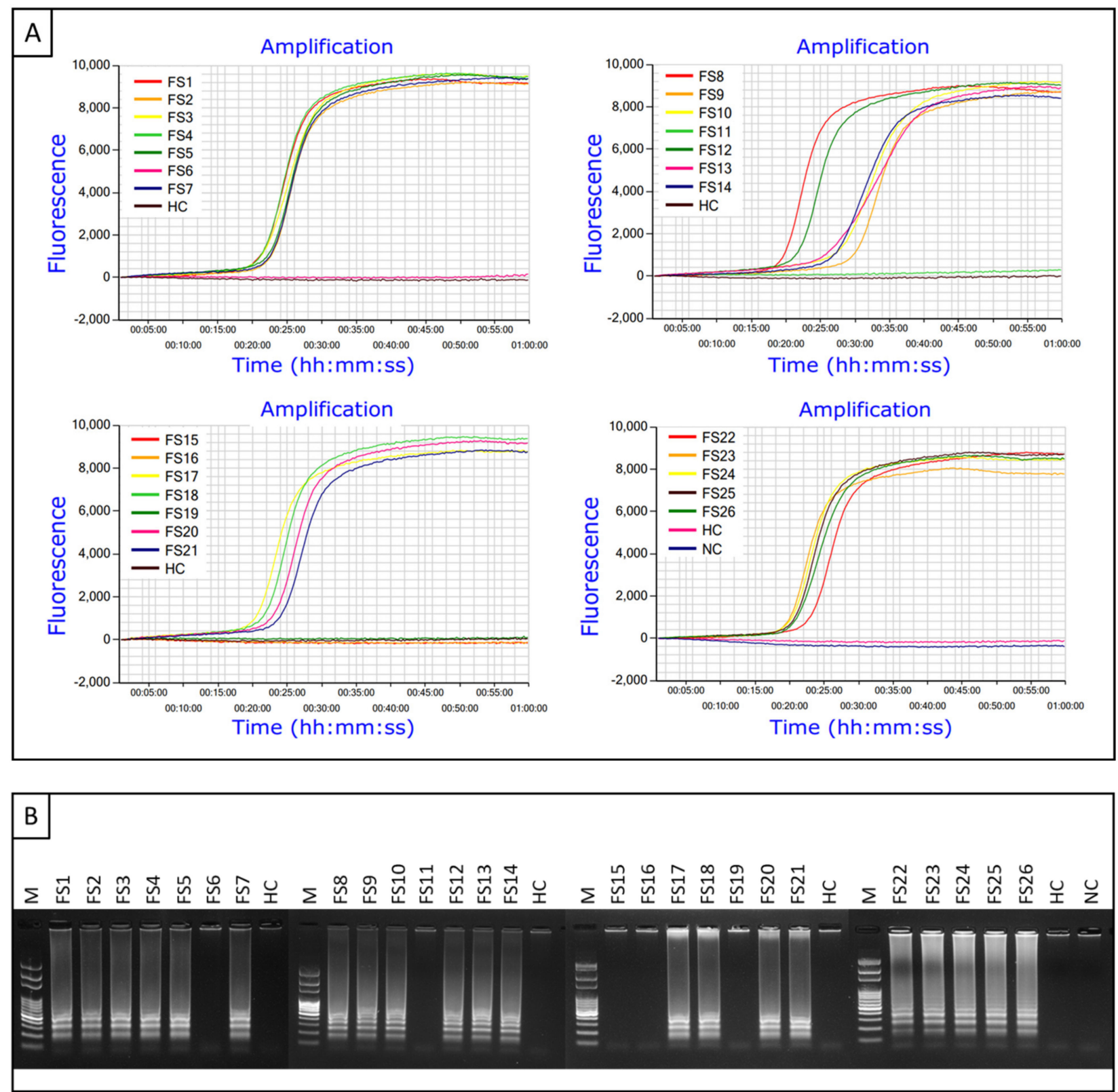

Figure 11. Detection of X. fastidiosa subsp. multiplex from infected field plant samples using probebased LAMP. Successful LAMP amplification of Xfm-infected plant tissues was visualized using real-time amplification with Genie ${ }^{\circledR}$ III (A) and with agarose gel imaging (B). Here, FS1 to FS26: 26 collected field infected samples positive for X. fastidiosa. M, $100 \mathrm{bp}$ ladder marker; HC, healthy blueberry leaf tissues as healthy control; $\mathrm{NC}$, nuclease free $\mathrm{H}_{2} \mathrm{O}$ used as the negative control.

\section{Discussion}

Bacterial leaf scorch (BLS) caused by $X f$ is a major concern for blueberry production in the southeastern United States. As $X f$ is a genetically diverse species with distinct subspecies that vary in host range and pathogenicity, management of this pathogen is often challenging. So far, two subspecies of $X f$ (i.e., $X f m$ and $X f f$ ) are reported to infect blueberry and cause BLS in blueberry plantings in southeastern Georgia [16,17]. In order to characterize the prevalence of these subspecies in blueberry and understand the origins of the isolates causing BLS in blueberry plantings, it is essential to precisely identify and differentiate between infections with these respective subspecies in Georgia blueberry production areas. 
Development of a single test that can be used in all conditions to identify these subspecies has not previously been reported. Combinations of multiple approaches for subspecies detection are described in several studies and vary in sensitivity, specificity and ease of use. A multiprimer PCR assay with three different targets was developed by Hernandez-Martinez et al. [48] to differentiate strains of X. fastidiosa infecting grape, almonds and oleander. Strains from three different subspecies (i.e., Xfm, Xff, and Xfs) were detected using this strategy. In another study carried out by Melanson et al. [49] on pecan, a combination of a multiprimer PCR assay with two other PCR-based techniques (i.e., enterobacterial repetitive intergenic consensus (ERIC)-PCR and repetitive extragenic palindromic (REP)-PCR was used to classify Xf strains. In addition, with those PCR assays, amplification and sequence analysis of the 16S-23S ITS and pglA gene was performed to confirm that $X f$ strains infecting pecan belong to subsp. multiplex [49]. Besides PCR based assays, a novel tetraplex qPCR assay was developed recently to identify $X f$ subspecies from a wide variety of hosts [50]. However, these techniques were not developed to differentiate between the Xff and Xfm strains present in blueberry. Recently, Faino et al. [51] leveraged Oxford Nanopore Technologies (ONT) MinION platform to detect and identify $X f$ at the subspecies and Sequence Type (ST) level. However, regardless of its advantages for detecting pathogen identity at subspecies level, ONTs MinION device has several drawbacks including having a high error rate, requiring frequent replacement of the flow cell, and requiring expertise to handle the data output (since contaminating sequence data could be misleading) [52].

Therefore, we developed two different methods that could be used to precisely identify the two subspecies of $X f$ (i.e., Xfm and Xff) causing BLS in blueberry from pure cultures or from infected blueberry plant material. A CAPS marker, which does not need any complex equipment or sequence analysis, and a LAMP assay, which is a rapid, sensitive, simple, and portable diagnostic method, were developed in this study. Using a single cut with the BtsI restriction enzyme (Figure 1A, Supplementary Figure S1), the CAPS marker could differentiate between the subspecies of pure culture of $X f$ blueberry isolates as well as greenhouse or field-grown plant samples infected with Xfm or Xff isolates (Figures 1 and 3 and Section 2.2). The 733-bp PCR product of the rpoD gene was cleaved by the BtsI enzyme at nt 124 of Xfm isolates and Xfm-infected samples, whereas PCR products from Xff isolates and Xff-infected plant samples remained undigested (Figures 1 and 3 and Section 2.2). In one of our previous studies, we determined the detection limit for the RST PCR primers to be between $2.5 \mathrm{pg}$ and $1.25 \mathrm{pg}$ of $X f$ genomic DNA per reaction [42] and, in the current study, we also observed that the CAPS marker could detect a distinctive PCR product at $2.5 \mathrm{pg}$ of $X f$ genomic DNA per reaction.

In addition to the CAPS marker, a LAMP assay was also developed for subspecies identification. Previously, a novel LAMP assay was developed targeting the 16S rRNA processing protein gene rim by Harper et al. [39] to detect Xf. That study used 20 isolates of $X f$ from four subspecies of the pathogen [39]. Nonetheless, the aim of that study was to detect $X f$ isolates regardless of subspecies, not to differentiate them based upon subspecies. Here, we designed the LAMP targeting SNPs, insertion and deletion mutations present in Xfm versus Xff isolates from blueberry (Figure 8, Supplementary Figure S3) to distinguish between blueberry isolates of the two subspecies. The LAMP assay was developed targeting the variations of Xfm isolates in rpoD sequences compared to Xff, since preliminary data revealed Xfm isolates as more prevalent in Georgia (Table 1, Figure 11) [17]. Optimization of the reaction temperature using DNA extracted from Xfm isolates as templates revealed $70^{\circ} \mathrm{C}$ as the optimum annealing temperature for the LAMP assay (Figure 5). The detection limit of the LAMP assay was determined to be $1 \mathrm{pg} / \mu \mathrm{L}$ of Xfm DNA (Figure 9, Supplementary Table S3). Successful amplification of Xfm isolates was observed (Figure 6) without cross-reaction with Xff isolates (Figure 7, Supplementary Figure S2), illustrating the high specificity of the LAMP assay described in our study. Moreover, the amplified products could be visualized using three different detection strategies: (1) agarose gel electrophoresis, (2) adding SYBR ${ }^{\circledR}$ Green I nucleic acid gel staining agent (Invitrogen) to the LAMP ampli- 
fied end product, and (3) real-time amplification by Genie ${ }^{\circledR}$ III (Figures 6 and 7), which made this assay a good substitute for other complicated and highly instrument-dependent molecular assays. The LAMP assay was also assessed with infected blueberry plant samples. However, as we initially observed inconsistencies among data outcome from the LAMP with plant samples, the LAMP primer sets were modified according to Kubota et al. [47]. Specifically, for use with the other five regular LAMP primers, we modified the backward loop primer (LB) by tagging it with a 6-carboxyl-flurescein (FAM) to act as an assimilating probe with a synthetic quench (Q) strand (Supplementary Figure S5, Supplementary Table S1). The optimum annealing temperature of this modified probe-based LAMP was the same at $70{ }^{\circ} \mathrm{C}$ as the regular LAMP (Supplementary Figure S6, Figure 6). However, it should be noted that a decreased sensitivity was observed for the modified LAMP probe/primer sets versus the regular LAMP reaction, where a true amplification curve was observed at $10 \mathrm{pg} / \mu \mathrm{L}$ rather than at $1 \mathrm{pg} / \mu \mathrm{L}$ (Supplementary Figure S7, Figure 7). Nonetheless, disregarding the lower sensitivity, successful detection of the Xfm infection from infected SHB blueberry plant samples without cross-reactions proves the field applicability of the modified probe-based LAMP assay (Figures 10 and 11). Thus, both of the LAMP assays can be used based on the aim of differentiating subspecies identity: the regular LAMP assay as a low-cost option to detect Xfm from culture grown isolates, and the modified probe-based LAMP assay to detect Xfm infection regardless of the origin of the samples (i.e., from both pure culture-grown isolates and infected blueberry plant materials). Future studies could focus on the development of a multiplex LAMP assay or CAPS markers targeting several subspecies of $X f$ in a single reaction to investigate any potential new subspecies that might infect blueberries.

Taken together, these results suggest that the CAPS marker and LAMP assays described herein could discriminate between Xfm and Xff by restriction digestion or by specific amplification of only Xfm isolates, preventing the need for further sequencing. Both of these assays could be used independently or in combination, applicable in various conditions, for the subspecies identification and differentiation of $X f$ isolates infecting blueberries. Accordingly, these assays represent a valuable diagnostic tool for disease surveillance to help characterize the distribution and diversity of $X f$ on a broad scale with higher throughput in blueberry production fields in the southeastern United States.

\section{Materials and Methods}

\subsection{Bacterial Isolates and Growth Conditions}

Seven distinct $X f$ isolates from two different subspecies of Xylella fastidiosa (i.e., $X$. fastidiosa subsp. fastidiosa (Xff) and X. fastidiosa subsp. multiplex (Xfm)) were originally cultured from symptomatic, naturally infected SHB blueberry plantings in Pierce and Bacon County, Georgia [17] and suspended in glycerol for long-term storage ( $>6$ months) at $-80^{\circ} \mathrm{C}$. The name, origin, and subspecies identity of each isolate utilized in this study are provided in Table 2 . The collected isolates were recovered from long-term storage by plating bacterial suspensions on PW (periwinkle wilt) [53] medium to extract DNA for molecular analysis and to mechanically inoculate greenhouse-grown blueberry plants for further analysis [53-55]. Two to three subcultures were used from each isolate to confirm the feasibility of the detection methods developed in this study. 
Table 2. Summary of Xylella fastidiosa isolates and sequences used in this study for in silico analyses and/or molecular detection assays.

\begin{tabular}{|c|c|c|c|c|c|c|}
\hline Isolate Name & $\begin{array}{l}\text { SHB } \\
\text { Cultivar }\end{array}$ & $\begin{array}{l}\text { Isolation } \\
\text { Location }\end{array}$ & Subsp ID ${ }^{a}$ & Used for $b$ & Reference & $\begin{array}{c}\text { RST } \\
\text { Accession } \\
\text { Number }\end{array}$ \\
\hline PierceMed1 & Meadowlark & $\begin{array}{l}\text { Pierce County, } \\
\text { GA, USA }\end{array}$ & Xff & $\begin{array}{l}\text { in silico analyses } \\
\text { and LAMP }\end{array}$ & Di Genova et al. [17] & MN590439 \\
\hline AlmaReb1 & Rebel & $\begin{array}{l}\text { Bacon County, } \\
\text { GA, USA }\end{array}$ & Xff & $\begin{array}{c}\text { in silico } \\
\text { analyses, } \\
\text { LAMP, and } \\
\text { CAPS }\end{array}$ & Di Genova et al. [17] & MN590433 \\
\hline AlmaReb2 & Rebel & $\begin{array}{l}\text { Bacon County, } \\
\text { GA, USA }\end{array}$ & Xff & $\begin{array}{c}\text { in silico } \\
\text { analyses, } \\
\text { LAMP, and } \\
\text { CAPS }\end{array}$ & Di Genova et al. [17] & MN590434 \\
\hline AlmaReb3 & Rebel & $\begin{array}{l}\text { Bacon County, } \\
\text { GA, USA }\end{array}$ & $X f m$ & $\begin{array}{c}\text { in silico } \\
\text { analyses, } \\
\text { LAMP, and } \\
\text { CAPS }\end{array}$ & Di Genova et al. [17] & MN590435 \\
\hline AlmaStar1 & Star & $\begin{array}{l}\text { Bacon County, } \\
\text { GA, USA }\end{array}$ & $X f m$ & $\begin{array}{c}\text { in silico } \\
\text { analyses, } \\
\text { LAMP, and } \\
\text { CAPS }\end{array}$ & Di Genova et al. [17] & MN590436 \\
\hline AlmaStar2 & Star & $\begin{array}{c}\text { Bacon County, } \\
\text { GA, USA }\end{array}$ & $X f m$ & $\begin{array}{c}\text { in silico analyses } \\
\text { and LAMP }\end{array}$ & Di Genova et al. [17] & MN590437 \\
\hline AlmaStar3 & Star & $\begin{array}{l}\text { Bacon County, } \\
\text { GA, USA }\end{array}$ & $X f m$ & $\begin{array}{c}\text { in silico analyses } \\
\text { and LAMP }\end{array}$ & Di Genova et al. [17] & MN590438 \\
\hline AlmaEm3 & Emerald & $\begin{array}{c}\text { Bacon County, } \\
\text { GA, USA }\end{array}$ & $X f m$ & $\begin{array}{l}\text { in silico } \\
\text { analyses only }\end{array}$ & Oliver et al. 2014 [22] & PUIY01000010 \\
\hline BB01 & V1 & $\begin{array}{c}\text { Brantley } \\
\text { County, GA, } \\
\text { USA }\end{array}$ & $X f m$ & $\begin{array}{l}\text { in silico } \\
\text { analyses only }\end{array}$ & Van Horn et al. 2017 [56] & MPAZ01000016 \\
\hline BB08-1 & Windsor & $\begin{array}{l}\text { Putnam County, } \\
\text { FL, USA }\end{array}$ & $X f m$ & $\begin{array}{l}\text { in silico } \\
\text { analyses only }\end{array}$ & Oliver et al. 2014 [22] & PUIZ01000048 \\
\hline BBI64 & V1 & $\begin{array}{c}\text { Brantley } \\
\text { County, GA, } \\
\text { USA }\end{array}$ & $X f m$ & $\begin{array}{l}\text { in silico } \\
\text { analyses only }\end{array}$ & Oliver et al. 2014 [22] & PUJA01000073 \\
\hline
\end{tabular}

a Xfm: Xylella fastidiosa subsp. multiplex, Xff: Xylella fastidiosa subsp. fastidiosa ${ }^{\mathrm{b}}$. "in silico" includes the analyses used to design the LAMP primers and CAPS marker, "LAMP" refers to the use of isolate DNA in the LAMP assay assessments, "CAPS" refers to the use of isolate DNA in the CAPS marker assessments.

\subsection{Plant Materials and Tissue Preparation}

To test the accuracy of the molecular assays developed in this study on known infected plants, blueberry plant samples inoculated with either Xff or Xfm isolates were collected from the greenhouse for bacterial subspecies detection and differentiation. The SHB cultivar 'Rebel' plants were grown in greenhouse conditions and inoculated with known isolates of $X f$ following the methods as reported by Oliver et al. [17]. Internodes (5-6" long) from SHB plants with 10 to 12 mature leaves were sampled for molecular analysis. For DNA extraction, leaf samples were surface sterilized with $5 \% \mathrm{NaOCl}$ solution. Uninoculated and inoculated blueberry plants were used as sources of negative and positive plant tissue controls.

\subsection{DNA Isolation}

The CTAB DNA extraction solution (G-Bioscience, St. Louis, MO, USA) was used for DNA preparations from bacterial cells and infected plant samples from the greenhouse and field with a slight modification to the recommended CTAB protocol by G-Bioscience [45]. Briefly, for DNA extraction from bacteria, inoculum was taken from PW [53] agar medium grown for 7 to 10 days at $28{ }^{\circ} \mathrm{C}$ using sterile, disposable inoculating loops. For plant 
samples, infected leaves were flash-frozen in liquid nitrogen and pulverized using a mortar and pestle. About $100 \mathrm{mg}$ of sample was used for DNA extraction. The collected bacterial cells and $100 \mathrm{mg}$ leaf samples were then re-suspended in $500 \mu \mathrm{L}$ of CTAB extraction solution containing 1\% PVP. Proteins and other cellular components were removed by using CTAB and by chloroform and isopropanol extractions according to the protocol described in Waliullah et al. [45]. The DNA pellet was washed with $500 \mu \mathrm{L}$ cold $70 \%$ ethanol in a final step during the extraction procedure, and nucleic acids were recovered $(12,000 \times g, 5 \mathrm{~min})$, resuspended in TE buffer $(10 \mathrm{mM}$ Tris-HCl, $0.5 \mathrm{mM}$ EDTA, pH 8), and either used immediately or stored at $-20^{\circ} \mathrm{C}$ for subsequent use. Total DNA yield and purity were estimated by measuring OD $260 \mathrm{~nm}$ and OD $260 \mathrm{~nm} / 280 \mathrm{~nm}$ with a NanoDrop spectrophotometer (NANODROP LITE, Thermo Scientific, Waltham, MA, USA).

\subsection{PCR Amplification of the Xf-Specific rpoD Gene}

PCR primer set RST 31/33 targeting RNA polymerase sigma-70 factor (rpoD), which has been widely accepted for the detection of the pathogen [55], was used to detect Xf from bacterial culture and blueberry leaf samples. PCR reactions were performed on a thermocycler (Bio-Rad-96 well T100 ${ }^{\mathrm{TM}}$, Bio-Rad, Hercules, CA, USA) using EconoTaq PLUS GREEN $2 \times$ Master Mix (Lucigen, Madison, WI, USA) according to the manufacturer's instructions. For PCR reactions with DNA extracted from pure bacterial cultures, $1 \mathrm{ng}$ of template DNA was used. For the analysis of the experimental samples from the greenhouse and field, $20 \mathrm{ng}$ of DNA was used in each reaction mixture. Each reaction contained the specified amount of template DNA with $0.3 \mu \mathrm{M}$ of each forward and reverse primer (Supplementary Table S1), $10 \mu \mathrm{L}$ of $2 \times$ Econotaq master mix (Lucigen), and deionized PCR grade water added to reach a final volume of $20 \mu \mathrm{L}$. PCR conditions for RST 31/33 were as follows: an initial denaturation step at $95^{\circ} \mathrm{C}$ for $2 \mathrm{~min}$ followed by 40 cycles of $30 \mathrm{~s}$ at $95{ }^{\circ} \mathrm{C}, 30 \mathrm{~s}$ at $58{ }^{\circ} \mathrm{C}, 45 \mathrm{~s}$ at $72{ }^{\circ} \mathrm{C}$ and final extension at $72{ }^{\circ} \mathrm{C}$ for $5 \mathrm{~min}$. PCR products were checked on a 1.0\% Tris-borate-EDTA (TBE) agarose gel. Samples were considered PCR positive when the DNA band of the expected size (733-bp) was clearly visualized after electrophoresis. Amplified products were purified with Quantum Prep ${ }^{\circledR}$ PCR Kleen Spin Columns (Bio-Rad) with a slight modification to the manufacturer's protocol.

\subsection{CAPS Marker Development and Analysis of the PCR Product}

To identify unique restriction sites between subspecies Xfm and Xff, all publicly available RNA polymerase sigma-70 factor rpoD gene sequences of Xff and Xfm isolates from blueberry (utilized in this study and from GenBank) were imported into Geneious v10.1.2 (Biomatters Ltd., Auckland, New Zealand) software (Figure 1A, Supplementary Figure S1, Table 2). For sequence alignment, the Align/Assemble > Pairwise/Multiple Align function using "Geneious Alignment" option with default settings were employed. The unique restriction site was identified using "Find Restriction Sites" option with default settings. Commonly used enzymes were searched to identify an appropriate candidate enzyme. The BtsI enzyme was selected to differentiate in between the two subspecies, as it has a unique restriction site present in Xfm (Figure 1A, Supplementary Figure S1) that is absent in Xff isolates from blueberry. To proceed with CAPS marker, $10 \mu \mathrm{L}$ of RST PCR product purified with Quantum Prep ${ }^{\circledR}$ PCR Kleen Spin Column (Bio-Rad) was digested with $0.5 \mu \mathrm{L}$ of BtsI-v2 restriction enzyme (NEB, Beverly, MA, USA) with $2.5 \mu \mathrm{L}$ of $10 \times$ NE Buffer and nuclease-free $\mathrm{H}_{2} \mathrm{O}$, totaling $25 \mu \mathrm{L}$ per reaction. The reaction mixture was incubated according to the manufacturer's protocol. The CAPS reaction products were separated by electrophoresis in 1.0\% TBE agarose gels following staining with GelGreen ${ }^{\circledR}$ Nucleic Acid Gel Stain (Biotium, Fremont, CA, USA) and visualized on a UV transilluminator UVP UVsolo touch (Analytik Jena, Upland, CA, USA).

\subsection{CAPS Analysis of PCR Product from Pure Bacterial Cultures and Infected Plant Samples}

RST PCR reactions were performed with the DNA from pure bacterial cultures (Section 4.1) and greenhouse-grown blueberry plants which had previously been inoc- 
ulated with Xfm or Xff isolates (Section 4.2). PCR products were digested with the BtsI-v2 restriction enzyme (NEB) following the methods described above (Section 4.5). Agarose gel electrophoresis was carried out with $5 \mu \mathrm{L}$ of the undigested and digested CAPS products concurrently.

\subsection{LAMP Primer Design}

The published RNA polymerase sigma-70 factor rpoD gene sequences for Xff and Xfm isolates from blueberry (Table 2) were aligned and searched for SNPs and in/del mutations (Section 4.5, Figure 8, Supplementary Figure S3, Table 2). Two in/del mutations and several other SNPs were found within the region of interest. Therefore, the region with the most variations in Xfm (relative to Xff) covering 204-bp of the rpoD gene was targeted for LAMP primer design using Primer Explorer version 5 (http: / / primerexplorer.jp/lampv5e/, accessed on 6 February 2022). The primers included two outer primers (F3 and B3), two inner primers (FIP and BIP), and two loop primers (LF, LB). For the FRET-based LAMP assay, besides the other 5 regular LAMP primers described above, the backward loop primer (LB) sequence was modified to generate the assimilating probe with a 6-carboxylflurescein (FAM) florescent tag and an associated quencher strand that is displaced by a BHQ -tagged quench (Q) strand during new strand synthesis (Supplementary Figure S5, Supplementary Table S1). Primers were synthesized by Sigma-Aldrich (St. Louis, MO, USA), dissolved in nuclease-free $\mathrm{H}_{2} \mathrm{O}$ (Sigma-Aldrich) to produce $100 \mu \mathrm{M}$ solutions, and stored at $-20^{\circ} \mathrm{C}$.

\subsection{Optimization of LAMP Conditions}

To optimize the reaction conditions of LAMP, total DNA extracted from pure cultures of $X \mathrm{fm}$ were used as a template. To determine the optimal reaction temperature, LAMP was performed from 66 to $73^{\circ} \mathrm{C}$ using $0.01 \mathrm{ng} / \mu \mathrm{L}$ of Xfm DNA sample diluted from the initially extracted DNA sample. The LAMP reaction was performed using Genie ${ }^{\circledR}$ III (OptiGene) real-time amplification system using LavaLAMPTM DNA Master Mix (Lucigen) according to the reaction mixture and protocol described below (Section 4.10). The amplification effectivity of the sample at the above-stated temperature range using the Genie ${ }^{\circledR}$ III system was assessed using two main parameters: amplification time $\left(\mathrm{Ti}_{\mathrm{amp}}\right)$ and amplicon annealing temperature $\left(\mathrm{T}_{\mathrm{a}}\right)$ [45]. The Genie ${ }^{\circledR} \mathrm{III}$ amplified product was also checked using agarose gel electrophoresis and visual observation was performed by adding $0.5 \mu \mathrm{L}$ of SYBR ${ }^{\mathrm{TM}}$ Green I DNA gel staining agent under UV irradiation (Invitrogen). The optimum time for amplification was determined to be $60 \mathrm{~min}$ according to the previous studies $[42,45,46]$.

\subsection{Reaction Conditions of LAMP}

The LAMP reaction was performed with LavaLAMP ${ }^{\mathrm{TM}}$ DNA Master Mix (Lucigen) in a $25 \mu \mathrm{L}$ mixture containing $2.5 \mu \mathrm{L}$ of primer mix, $12.5 \mu \mathrm{L} 2 \times$ Lava LAMPTM DNA Master Mix, $1 \mu \mathrm{L}$ Green Fluorescent Dye (Lucigen), $1 \mu \mathrm{L}$ of DNA template, and nuclease-free $\mathrm{H}_{2} \mathrm{O}$ added up to the desired total volume. The $10 \times$ formulation for the regular LAMP was: $1.6 \mu \mathrm{M}$ each of FIP and BIP; $0.2 \mu \mathrm{M}$ each of F3 and B3; $0.8 \mu \mathrm{M}$ each of LF and LB, respectively. By contrast, for FRET-based "probe LAMP" assay, in addition with $0.2 \mu \mathrm{M}$ of F3 and B3 and 1.6 $\mu \mathrm{M}$ of FIP and BIP, the $10 \times$ formulation of the primer mix contained $0.1 \mu \mathrm{M}$ of the quench $(\mathrm{Q})$ strand and $0.2 \mu \mathrm{M}$ of the FAM-tagged modified backward loop primer (or assimilating probe LB-F, Supplementary Figure S5, Supplementary Table S1) with $0.8 \mu \mathrm{M}$ of LF primer. For LAMP amplification, the Genie ${ }^{\circledR}$ III real-time amplification system was used and the data was analyzed using Genie explorer software (OptiGene). Genie $^{\circledR}$ III amplified products were further analyzed by $1 \%$ agarose gel electrophoresis for visual inspection and with SYBR ${ }^{\mathrm{TM}}$ Green 1 nucleic acid gel stain (Invitrogen) for naked-eye observation. The mixture was preheated at $90^{\circ} \mathrm{C}$ for $3 \mathrm{~min}$, amplified at $70^{\circ} \mathrm{C}$ for $60 \mathrm{~min}$, and then terminated at a range from 98 to $80^{\circ} \mathrm{C}$, with a decline rate of $0.05^{\circ} \mathrm{C}$ per second. 


\subsection{Specificity Analysis of LAMP}

The specificity of LAMP primers for the detection of Xfm was examined using $0.1 \mathrm{ng}$ of DNA extracted from pure bacterial cultures of Xfm isolates AlmaReb3 and AlmaStar1 and Xff isolates AlmaReb1 and AlmaReb2. An additional specificity test was carried out with 7 isolates ( 3 Xff and 4 Xfm) from both subspecies (Table 2). The DNA extraction from pure culture and the LAMP assay were performed according to the methods described above (Sections 4.3 and 4.8-4.10). Nuclease-free $\mathrm{H}_{2} \mathrm{O}$ was used as negative control.

\subsection{Sensitivity Analysis of LAMP}

The sensitivity of LAMP primers to amplify Xfm was examined using $10 \mathrm{ng} / \mu \mathrm{L}$ to $0.1 \mathrm{fg} / \mu \mathrm{L}$ of DNA extracted from Xfm isolate AlmaReb3. The assay was executed according to the method described above. Nuclease-free $\mathrm{H}_{2} \mathrm{O}$ was used as negative control.

\subsection{Evaluation of Infected Field Samples Using CAPS Marker and LAMP Assay}

Samples were taken from SHB blueberry plants with bacterial leaf scorch (BLS) symptoms from fields located in three different counties (Bacon, Pierce, and Ware counties) in the state of Georgia to detect and differentiate between the two subspecies of $X f$ infecting blueberry. Leaf samples were collected from at least five plants per site showing typical BLS symptoms (Table 1, Supplementary Figure S4). From each sample, total DNA was extracted from between three to five midribs and petioles of collected leaf material using a modified CTAB protocol (G-Biosciences, St. Louis, MO, USA). The Xf-positive samples were screened by polymerase chain reaction (PCR) testing using the RST31/33 primer pair [55]. Twenty-six Xf positive samples were selected for further CAPS based and probe-based LAMP analysis for subspecies identification according to the protocol described above. Subspecies identity was further confirmed by direct sequencing of the PCR product by Sanger sequencing.

\section{Conclusions}

BLS, which is caused by the two subspecies of Xylella fastidiosa (Xf), X. fastidiosa subsp. Multiplex (Xfm) and X. fastidiosa subsp. Fastidiosa (Xff) is a growing concern for blueberry producers in the southeastern United States. Robust methods for subspecies identification to investigate into the origins of isolates causing $X f$ outbreaks are indispensable. Unfortunately, the available detection techniques are unable to easily differentiate between the $X f f$ and Xfm isolates infecting blueberry, and sequencing-based methods can be lengthy, costly, and relatively low throughput. Therefore, we developed two independent detection techniques: a CAPS marker and a LAMP assay to vigorously discriminate between the $\mathrm{Xfm}$ and Xff subspecies infecting blueberries. These methods were developed targeting either unique restriction sites or the in/del mutations and SNPs in RNA polymerase sigma-70 factor $(r p o D)$ gene sequence of Xfm versus Xff. With these detection methods, Xfm was reliably detected and differentiated from pure culture grown, infected field-grown and inoculated greenhouse-grown Xff blueberry samples. Moreover, LAMP detection of Xfm (versus Xff) with three different approaches including gel electrophoresis, SYBR ${ }^{\mathrm{TM}}$ Green I DNA staining, or with Genie ${ }^{\circledR}$ III allowed the detection method to be applicable in lab conditions and in the field. Taken together, our results demonstrate that both of our detection methods have the potential to rapidly and reliably enable differentiation between the $X f$ subspecies causing BLS in blueberry in the southeastern United States.

Supplementary Materials: The following are available online at https:/ /www.mdpi.com/article/10 .3390/ijms23041937/s1.

Author Contributions: Conceptualization, M.E.A. and J.E.O.; data curation, S.W.; formal analysis, S.W. and D.D.G.; funding acquisition, M.E.A. and J.E.O.; investigation, M.E.A.; methodology, S.W.; project administration, M.E.A.; resources, J.E.O.; software, S.W.; supervision, M.E.A.; writing-original draft, S.W.; writing-review and editing, S.W., J.E.O., D.D.G. and M.E.A. All authors have read and agreed to the published version of the manuscript. 
Funding: This research was partially supported by the USDA National Institute of Food and Agriculture, HATCH project no. 1016575, a Georgia Farm Bureau Grant, a Georgia Blueberry Commodity Commission Grant, and a grant jointly funded by the UGA College of Agricultural and Environmental Sciences, Office of Research, and Department of Plant Pathology.

Acknowledgments: We would like to thank the Georgia blueberry growers who allowed us to collect the field samples utilized in this work.

Conflicts of Interest: The authors declare no conflict of interest.

\section{References}

1. EFSA (European Food Safety Authority). Update of the Xylella spp. host plant database-systematic literature searches up to 30 June 2019. EFSA J. 2020, 18, 6114.

2. Su, C.C.; Deng, W.L.; Jan, F.J.; Chang, C.J.; Huang, H.; Shih, H.T.; Chen, J. Xylella taiwanensis sp. nov., causing pear leaf scorch disease. Int. J. Syst. Evol. Microbiol. 2016, 66, 4766-4771. [CrossRef] [PubMed]

3. Saponari, M.; Boscia, D.; Altamura, G.; Loconsole, G.; Zicca, S.; D’Attoma, G.; Morelli, M.; Palmisano, F.; Saponari, A.; Tavano, D. Isolation and pathogenicity of Xylella fastidiosa associated to the olive quick decline syndrome in southern Italy. Sci. Rep. 2017, 7, 17723. [CrossRef] [PubMed]

4. Almeida, R.P.; Purcell, A.H. Biological traits of Xylella fastidiosa strains from grapes and almonds. Appl. Environ. Microbiol. 2003, 69, 7447-7452. [CrossRef] [PubMed]

5. Baldi, P.; La Porta, N. Xylella fastidiosa: Host range and advance in molecular identification techniques. Front. Plant Sci. 2017, 8, 944. [CrossRef]

6. Stevenson, J.F.; Matthews, M.A.; Rost, T.L. The developmental anatomy of Pierce's disease symptoms in grapevines: Green islands and matchsticks. Plant Dis. 2005, 89, 543-548. [CrossRef] [PubMed]

7. Chang, C.-J.; Donaldson, R.; Brannen, P.; Krewer, G.; Boland, R. Bacterial leaf scorch, a new blueberry disease caused by Xylella fastidiosa. HortScience 2009, 44, 413-417. [CrossRef]

8. Harmon, P.; Hopkins, D. First report of bacterial leaf scorch caused by Xylella fastidiosa on southern highbush blueberry in Florida. Plant Dis. 2009, 93, 1220. [CrossRef] [PubMed]

9. Brannen, P.M.; Krewer, G.W.; Robert, T., Jr.; Horton, D.L.; Chang, C.-J. Bacterial leaf scorch of blueberry. Univ. Ga. Coop. Ext. 2016.

10. Blua, M.J.; Redak, R.A.; Morgan, D.J.W.; Costa, H.S. Seasonal flight activity of two Homalodisca species (Homoptera: Cicadellidae) that spread Xylella fastidiosa in southern California. J. Econ. Entomol. 2001, 94, 1506-1510. [CrossRef]

11. Almeida, R.P.; Nunney, L. How do plant diseases caused by Xylella fastidiosa emerge? Plant Dis. 2015, 99, 1457-1467. [CrossRef] [PubMed]

12. Tertuliano, M.; Srinivasan, R.; Scherm, H. Settling behavior of the glassy-winged sharpshooter, Homalodisca vitripennis, vector of Xylella fastidiosa, on southern highbush blueberry cultivars. Entomol. Exp. Appl. 2012, 143, 67-73. [CrossRef]

13. Denancé, N.; Briand, M.; Gaborieau, R.; Gaillard, S.; Jacques, M.-A. Identification of genetic relationships and subspecies signatures in Xylella fastidiosa. BMC Genom. 2019, 20, 239. [CrossRef] [PubMed]

14. Nunney, L.; Hopkins, D.L.; Morano, L.D.; Russell, S.E.; Stouthamer, R. Intersubspecific recombination in Xylella fastidiosa strains native to the United States: Infection of novel hosts associated with an unsuccessful invasion. Appl. Environ. Microbiol. 2014, 80, 1159-1169. [CrossRef]

15. Parker, J.K.; Havird, J.C.; De La Fuente, L. Differentiation of Xylella fastidiosa strains via multilocus sequence analysis of environmentally mediated genes (MLSA-E). Appl. Environ. Microbiol. 2012, 78, 1385-1396. [CrossRef]

16. Oliver, J.; Cobine, P.; De La Fuente, L. Xylella fastidiosa isolates from both subsp. multiplex and fastidiosa cause disease on southern highbush blueberry (Vaccinium sp.) under greenhouse conditions. Phytopathology 2015, 105, 855-862. [CrossRef]

17. Di Genova, D.; Lewis, K.J.; Oliver, J.E. Natural Infection of Southern Highbush Blueberry (Vaccinium corymbosum Interspecific Hybrids) by Xylella fastidiosa subsp. fastidiosa. Plant Dis. 2020, 104, 2598-2605. [CrossRef] [PubMed]

18. Nunney, L.; Ortiz, B.; Russell, S.A.; Sánchez, R.R.; Stouthamer, R. The complex biogeography of the plant pathogen Xylella fastidiosa: Genetic evidence of introductions and subspecific introgression in Central America. PLoS ONE 2014, 9 , e112463. [CrossRef]

19. Hopkins, D.; Purcell, A. Xylella fastidiosa: Cause of Pierce's disease of grapevine and other emergent diseases. Plant Dis. 2002, 86, 1056-1066. [CrossRef]

20. Killiny, N.; Almeida, R.P. Gene regulation mediates host specificity of a bacterial pathogen. Environ. Microbiol. Rep. 2011, 3, 791-797. [CrossRef]

21. Hopkins, D.; Harmon, P.; Brannen, P. Host range of Xylella fastidiosa strains that cause blueberry leaf scorch. Proc. Phytopathol. 2012, 102, 55.

22. Oliver, J.; Sefick, S.; Parker, J.; Arnold, T.; Cobine, P.; De La Fuente, L. Ionome changes in Xylella fastidiosa-Infected Nicotiana tabacum correlate with virulence and discriminate between subspecies of bacterial isolates. Mol. Plant Microbe Interact. 2014, 27, 1048-1058. [CrossRef]

23. Pooler, M.R.; Hartung, J.S. Specific PCR detection and identification of Xylella fastidiosa strains causing citrus variegated chlorosis. Curr. Microbiol. 1995, 31, 377-381. [CrossRef] 
24. Chen, J.; Chang, C.; Jarret, R.; Gawel, N. Genetic variation among Xylella fastidiosa strains. Phytopathology 1992, 82, 973-977. [CrossRef]

25. Chen, J.; Lamikanra, O.; Chang, C.; Hopkins, D. Randomly amplified polymorphic DNA analysis of Xylella fastidiosa Pierce's disease and oak leaf scorch pathotypes. Appl. Environ. Microbiol. 1995, 61, 1688-1690. [CrossRef] [PubMed]

26. Chen, J.; Hartung, J.S.; Chang, C.-J.; Vidaver, A.K. An evolutionary perspective of Pierce's disease of grapevine, citrus variegated chlorosis, and mulberry leaf scorch diseases. Curr. Microbiol. 2002, 45, 0423-0428. [CrossRef] [PubMed]

27. Banks, D.; Albibi, R.; Chen, J.; Lamikanra, O.; Jarret, R.L.; Smith, B.J. Specific detection of Xylella fastidiosa Pierce's disease strains Curr. Microbiol. 1999, 39, 85-88. [CrossRef]

28. Huang, Q. Specific detection and identification of Xylella fastidiosa strains causing oleander leaf scorch using polymerase chain reaction. Curr. Microbiol. 2009, 58, 393-398. [CrossRef]

29. Guan, W.; Shao, J.; Elbeaino, T.; Davis, R.E.; Zhao, T.; Huang, Q. Specific detection and identification of American mulberryinfecting and Italian olive-associated strains of Xylella fastidiosa by polymerase chain reaction. PLoS ONE 2015, 10, e0129330. [CrossRef]

30. Bleve, G.; Marchi, G.; Ranaldi, F.; Gallo, A.; Cimaglia, F.; Francesco Logrieco, A.; Mita, G.; Ristori, J.; Surico, G. Molecular characteristics of a strain (Salento-1) of Xylella fastidiosa isolated in Apulia (Italy) from an olive plant with the quick decline syndrome. In Phytopathologia Mediterranea; Firenze University Press: Florence, Italy, 2016; pp. 139-146.

31. Pooler, M.; Myung, I.; Bentz, J.; Sherald, J.; Hartung, J. Detection of Xylella fastidiosa in potential insect vectors by immunomagnetic separation and nested polymerase chain reaction. Lett. Appl. Microbiol. 1997, 25, 123-126. [CrossRef]

32. Buzkan, N.; Krivanek, A.F.; Eskalen, A.; Walker, M.A. Improvements in sample preparation and polymerase chain reaction techniques for detection of Xylella fastidiosa in grapevine tissue. Am. J. Enol. Vitic. 2003, 54, 307-312.

33. Ciapina, L.; Carareto Alves, L.; Lemos, E. A nested-PCR assay for detection of Xylella fastidiosa in citrus plants and sharpshooter leafhoppers. J. Appl. Microbiol. 2004, 96, 546-551. [CrossRef]

34. Mang, S.M.; Frisullo, S.; Elshafie, H.S.; Camele, I. Diversity evaluation of Xylella fastidiosa from infected olive trees in Apulia (Southern Italy). Plant Pathol. J. 2016, 32, 102-111. [CrossRef] [PubMed]

35. Francis, M.; Lin, H.; Cabrera-La Rosa, J.; Doddapaneni, H.; Civerolo, E.L. Genome-based PCR primers for specific and sensitive detection and quantification of Xylella fastidiosa. Eur. J. Plant Pathol. 2006, 115, 203-213. [CrossRef]

36. Bextine, B.; Child, B. Xylella fastidiosa genotype differentiation by SYBR ${ }^{\circledR}$ Green-based QRT-PCR. FEMS Microbiol. Lett. 2007, 276, 48-54. [CrossRef]

37. Guan, W.; Shao, J.; Singh, R.; Davis, R.E.; Zhao, T.; Huang, Q. A TaqMan-based real time PCR assay for specific detection and quantification of Xylella fastidiosa strains causing bacterial leaf scorch in oleander. J. Microbiol. Methods 2013, 92, 108-112. [CrossRef]

38. Li, W.; Teixeira, D.C.; Hartung, J.S.; Huang, Q.; Duan, Y.; Zhou, L.; Chen, J.; Lin, H.; Lopes, S.; Ayres, A.J. Development and systematic validation of qPCR assays for rapid and reliable differentiation of Xylella fastidiosa strains causing citrus variegated chlorosis. J. Microbiol. Methods 2013, 92, 79-89. [CrossRef]

39. Harper, S.; Ward, L.; Clover, G. Development of LAMP and real-time PCR methods for the rapid detection of Xylella fastidiosa for quarantine and field applications. Phytopathology 2010, 100, 1282-1288. [CrossRef]

40. Dupas, E.; Legendre, B.; Olivier, V.; Poliakoff, F.; Manceau, C.; Cunty, A. Comparison of real-time PCR and droplet digital PCR for the detection of Xylella fastidiosa in plants. J. Microbiol. Methods 2019, 162, 86-95. [CrossRef]

41. Yaseen, T.; Drago, S.; Valentini, F.; Elbeaino, T.; Stampone, G.; Digiaro, M.; D'ONGHIA, A.M. On-site detection of Xylella fastidiosa in host plants and in" spy insects" using the real-time loop-mediated isothermal amplification method. Phytopathol. Mediterr. 2015, 54, 488-496.

42. Waliullah, S.; Hudson, O.; Oliver, J.E.; Brannen, P.M.; Ji, P.; Ali, M.E. Comparative analysis of different molecular and serological methods for detection of Xylella fastidiosa in blueberry. PLoS ONE 2019, 14, e0221903. [CrossRef]

43. Silvester, R.; Alexander, D.; Antony, A.C.; Hatha, M. GroEL PCR-RFLP-An efficient tool to discriminate closely related pathogenic Vibrio species. Microb. Pathog. 2017, 105, 196-200. [CrossRef]

44. Kularatne, H.G.C.; Lawrie, A.C.; Barber, P.A.; Keane, P.J. A specific primer PCR and RFLP assay for the rapid detection and differentiation in planta of some Mycosphaerella species associated with foliar diseases of Eucalyptus globulus. Mycol. Res. 2004, 108, 1476-1493. [CrossRef]

45. Waliullah, S.; Ling, K.-S.; Cieniewicz, E.J.; Oliver, J.E.; Ji, P.; Ali, M.E. Development of loop-mediated isothermal amplification assay for rapid detection of Cucurbit leaf crumple virus. Int. J. Mol. Sci. 2020, 21, 1756. [CrossRef] [PubMed]

46. Waliullah, S.; Bell, J.; Jagdale, G.; Stackhouse, T.; Hajihassani, A.; Brenneman, T.; Ali, M.E. Rapid detection of pecan root-knot nematode, Meloidogyne partityla, in laboratory and field conditions using loop-mediated isothermal amplification. PLoS ONE 2020, 15, e0228123.

47. Kubota, R.; Alvarez, A.; Su, W.; Jenkins, D. FRET-based assimilating probe for sequence-specific real-time monitoring of loop-mediated isothermal amplification (LAMP). Biol. Eng. Trans. 2011, 4, 81-100. [CrossRef]

48. Hernandez-Martinez, R.; Costa, H.; Dumenyo, C.; Cooksey, D. Differentiation of strains of Xylella fastidiosa infecting grape, almonds, and oleander using a multiprimer PCR assay. Plant Dis. 2006, 90, 1382-1388. [CrossRef] [PubMed]

49. Melanson, R.; Sanderlin, R.; McTaggart, A.; Ham, J. A systematic study reveals that Xylella fastidiosa strains from pecan are part of X. fastidiosa subsp. multiplex. Plant Dis. 2012, 96, 1123-1134. [CrossRef] [PubMed] 
50. Dupas, E.; Briand, M.; Jacques, M.-A.; Cesbron, S. Novel tetraplex quantitative PCR assays for simultaneous detection and identification of Xylella fastidiosa subspecies in plant tissues. Front. Plant Sci. 2019, 10, 1732. [CrossRef] [PubMed]

51. Faino, L.; Scala, V.; Albanese, A.; Modesti, V.; Grottoli, A.; Pucci, N.; Doddi, A.; L'Aurora, A.; Tatulli, G.; Reverberi, M. Nanopore sequencing for the detection and identification of Xylella fastidiosa subspecies and sequence types from naturally infected plant material. Plant Pathol. 2019, 70, 1860-1870. [CrossRef]

52. Tyler, A.D.; Mataseje, L.; Urfano, C.J.; Schmidt, L.; Antonation, K.S.; Mulvey, M.R.; Corbett, C.R. Evaluation of Oxford Nanopore's MinION Sequencing Device for Microbial Whole Genome Sequencing Applications. Sci. Rep. 2018, 8, 10931. [CrossRef] [PubMed]

53. Davis, M.J.; French, W.J.; Schaad, N.W. Axenic culture of the bacteria associated with phony disease of peach and plum leaf scald. Curr. Microbiol. 1981, 6, 309-314. [CrossRef]

54. Davis, M.J.; Purcell, A.H.; Thomson, S.V. Isolation media for the Pierce's disease bacterium. Phytopathology 1980, 70, 425-429. [CrossRef]

55. Minsavage, G.; Thompson, C.; Hopkins, D.; Leite, R.; Stall, R. Development of a polymerase chain reaction protocol for detection of Xylella fastidiosa in plant tissue. Phytopathology 1994, 84, 456-461. [CrossRef]

56. Van Horn, C.; Chang, C.-J.; Chen, J. De novo whole-genome sequence of Xylella fastidiosa subsp. multiplex strain BB01 isolated from a blueberry in Georgia, USA. Genome Announc. 2017, 5, e01598-16. [CrossRef] [PubMed] 